\title{
Minor Withanolides from Physalis philadelphica: Structures, Quinone Reductase Induction Activities, and Liquid Chromatography (LC)- MS-MS Investigation as Artifacts
}

\author{
Jian-Qiao Gu, Wenkui Li, Young-Hwa Kang, Bao-Ning Su, Harry H. S. Fong, \\ Richard B. van Breemen, John M. Pezzuto, and A. Douglas Kinghorn*
}

Program for Collaborative Research in the Pharmaceutical Sciences and Department of Medicinal Chemistry and Pharmacognosy, College of Pharmacy, University of Illinois at Chicago; Chicago, IL 60612, U.S.A.

Received December 24, 2002; accepted January 29, 2003

\begin{abstract}
As a result of a bioactivity-guided search for novel, plant-derived cancer chemopreventive agents, ixocarpalactone A (5) was isolated previously as a potent quinone reductase inducer from the leaves and stems of Physalis philadelphica. In the present study, this promising lead compound was reisolated in gram quantities for in vivo biological testing. During the course of this work, four additional minor new withanolides were also obtained and characterized, namely, 2,3-dihydro-3 $\beta$-methoxyixocarpalactone $A$ (1), 2,3-dihydro-3 $\beta$-methoxyixocarpalactone $B(2), 2,3$-dihydroixocarpalactone $B(3)$, and $4 \beta, 7 \beta, 20 R$-trihydroxy-1-oxowitha-2,5-dien-22,26-olide (4). However, compounds 1 and 2 were determined using liquid chromatography (LC)-MS-MS to be artifacts generated during the extraction and isolation procedure. Ixocarpalactone $A$ was detected in the fresh fruits (tomatillos) of $P$. philadelphica by LC-MS-MS analysis at a concentration of $143 \pm 4.53 \mathrm{ppb}$.
\end{abstract}

Key words Physalis philadelphica; withanolide; ixocarpalactone A; quinone reductase induction; artifact; liquid chromatography (LC)-MS-MS

The withanolides are a group of $\mathrm{C}-28$ steroidal lactones which occur primarily in 12 genera of the plant family Solanaceae. ${ }^{1-3)}$ Representatives of this compound class have been previously evaluated for their antifeedant, anti-inflammatory, antitumor, cytotoxic, and immunomodulatory activities and for protection against $\mathrm{CCl}_{4}$-induced hepatotoxicity. ${ }^{4,5)}$ Recently, over 30 withanolides have been investigated in our laboratory for their potential to induce the phase II enzyme quinone reductase in cultured Hepa lclc7 mouse hepatoma cells. ${ }^{6-8)}$ One of the most promising compounds to emerge from this study is ixocarpalactone A (5), which was isolated and characterized from the aerial parts of Physalis philadelphica LAm. (Solanaceae) (formerly known as P. ixocarpa Ввот.). ${ }^{8,9)}$ The fruits of this species, known as "tomatillos", () are consumed in enchiladas, salsas and other foods in North America. ${ }^{10)}$ As part of our ongoing project on the discovery and evaluation of naturally occurring cancer chemopreventive agents, ${ }^{11,12)}$ it was decided to reisolate ixocarpalactone A (5) in gram quantities for the evaluation of its in vivo biological activity in a full-term animal tumorigenesis model. Background information on the botany, ethnobotany, and biological activity of $P$. philadelphica has been provided in our previous contributions on this plant. ${ }^{6-8)}$

In the current work, fractionation of a methanolic extract of the leaves and stems of P. philadelphica led to the isolation of four new withanolides, 2,3 -dihydro-3 $\beta$-methoxyixocarpalactone A (1), 2,3-dihydro-3 $\beta$-methoxyixocarpalactone B (2), 2,3-dihydroixocarpalactone B (3), and $4 \beta, 7 \beta, 20 R$-trihydroxy-1-oxowitha-2,5-dien-22,26-olide (4), along with gram quantities of ixocarpalactone A (5) (Fig. 1). The structure elucidation of the new compounds was carried out through extensive spectral data interpretation, and the isolates were evaluated for potential to induce quinone reductase in Hepa $1 \mathrm{c} 1 \mathrm{c} 7$ cells. $^{7,13)}$

More than ten methoxylated and ethoxylated withanolides (such as 2,3-dihydro-3 $\beta$-methoxywithaferin A, 2,3-dihydro-
$3 \beta$-ethoxywithaferin $\mathrm{A}$, and 4,5-dihydro-5 $\alpha$-methoxyjaborosalactone B) have been hypothesized to be Michael addition adducts due to treatment with alcohols in the extraction and purification processes of these compounds. ${ }^{2,14-21)}$ This hypothesis was confirmed experimentally, for example, by heating withaferin $\mathrm{A}$ in $\mathrm{MeOH}$ or treating this compound with sodium acetate in $\mathrm{MeOH}$, to afford 2,3-dihydro-3 $\beta$-methoxywithaferin $\mathrm{A}$ in either case. ${ }^{18-20)}$ Thus, it was considered of interest to determine if the methoxylated compounds $\mathbf{1}$ and $\mathbf{2}$ are extraction artifacts or naturally occurring substances.

A larger number of withanolides have been isolated from the aerial parts of $P$. philadelphica than from the edible fruits. ${ }^{3,6,8,9)}$ So far, ixocarpalactone A (5) has not been detected in the fruits of $P$. philadelphica. Thus, the presence of this compound in a tomatillo sample was also investigated in the current study. We report herein the isolation from the aerial parts of P. philadelphica and the structural determination
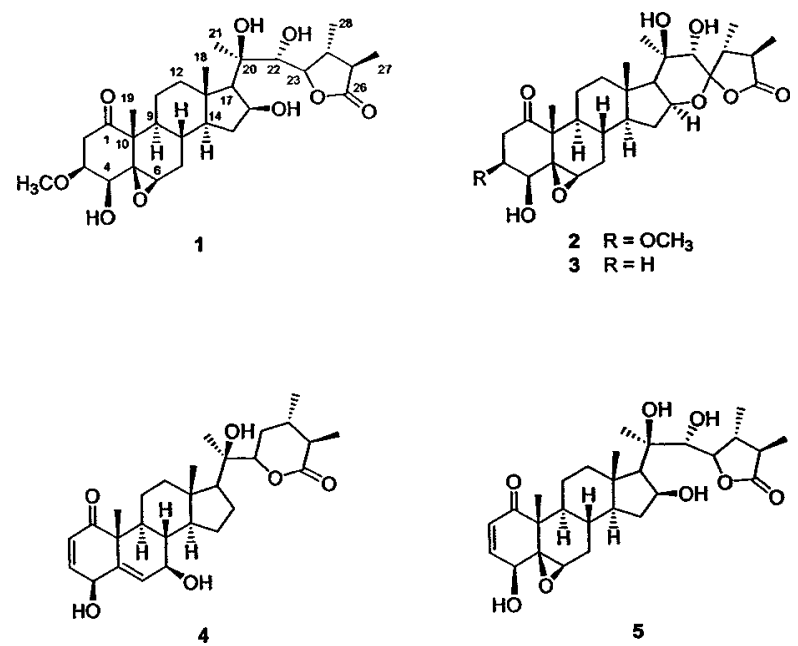

Fig. 1. Structures of Minor Withanolides (1-4) and Ixocarpalactone A (5) Isolated from Physalis philadelphica 
of compounds $\mathbf{1}-\mathbf{4}$, their biological evaluation in terms of the induction of quinone reductase in Hepa 1c1c7 cells, an investigation into their possible artifactual nature, and the quantification of ixocarpalactone A (5) in the fresh fruits of P. philadelphica.

\section{Results and Discussion}

Ixocarpalactone A (5) was the major compound found in the EtOAc-soluble extract of the leaves and stems of $P$. philadelphica in the present investigation, and was obtained in a yield of $c a .0 .0088 \% \mathrm{w} / \mathrm{w}(88 \mathrm{ppm})$ of the dried plant material. Compound 5 was crystallized in $\mathrm{CHCl}_{3}-\mathrm{MeOH}$ (20:1) and identified by comparison of its physical and spectroscopic data with those of an authentic sample and reported values. ${ }^{8)}$ This compound was originally reported by Kirson et al. in 1979, ${ }^{9)}$ and its relative and absolute configurations were recently confirmed by X-ray crystallography and Mosher ester methodology, respectively. ${ }^{8)}$

Compound 1 was isolated as a white amorphous powder, mp $240-243^{\circ} \mathrm{C}$, and $[\alpha]_{\mathrm{D}}^{20}-39^{\circ}\left(c=0.088, \mathrm{CH}_{3} \mathrm{CN}\right)$, and its molecular formula was determined to be $\mathrm{C}_{29} \mathrm{H}_{44} \mathrm{O}_{9}$ by high-resolution (HR)-MS (obsd $m / z 537.3068[\mathrm{M}+\mathrm{H}]^{+}$). The ${ }^{1} \mathrm{H}-\mathrm{NMR}$ spectrum (in $\mathrm{CDCl}_{3}$ ) of compound 1 (Table 1 ) displayed characteristic signals for five methyl groups $\left[\delta_{\mathrm{H}} 1.11\right.$ $\left(3 \mathrm{H}, \mathrm{s}, \mathrm{CH}_{3}-18\right), 1.17\left(3 \mathrm{H}, \mathrm{d}, J=7.1 \mathrm{~Hz}, \mathrm{CH}_{3}-27\right), 1.25(3 \mathrm{H}$, d, $\left.J=6.8 \mathrm{~Hz}, \mathrm{CH}_{3}-28\right), 1.29\left(3 \mathrm{H}, \mathrm{s}, \mathrm{CH}_{3}-19\right), 1.30(3 \mathrm{H}, \mathrm{s}$, $\left.\left.\mathrm{CH}_{3}-21\right)\right]$, and one methoxyl group $\left[\delta_{\mathrm{H}} 3.36\left(3 \mathrm{H}, \mathrm{s}, \mathrm{OCH}_{3}-\right.\right.$ $3)]$. The ${ }^{13} \mathrm{C}-\mathrm{NMR}$ and distortionless enhancement by polarization transfer (DEPT) spectra of 1 (Table 3) disclosed 29 carbons, which were indicative of a ketone $\left[\delta_{\mathrm{C}} 210.9(\mathrm{C}-1)\right]$, a $\gamma$-lactone carbonyl $\left[\delta_{\mathrm{C}} 181.8(\mathrm{C}-26)\right]$, five oxygenated methines $\left[\delta_{\mathrm{C}} 72.8(\mathrm{C}-16), 73.1(\mathrm{C}-22), 74.5(\mathrm{C}-4), 77.8(\mathrm{C}-3)\right.$, $79.0(\mathrm{C}-23)]$, an epoxide functional group $\left[\delta_{\mathrm{C}} 58.9(\mathrm{C}-6)\right.$, $65.0(\mathrm{C}-5)]$, one methoxyl $\left[\delta_{\mathrm{C}} 57.0\left(\mathrm{OCH}_{3}-3\right)\right]$, one oxygenated quaternary carbon $\left[\delta_{\mathrm{C}} 79.4(\mathrm{C}-20)\right]$, in addition to five methyls, five methylenes, six other methines, and two additional quaternary carbons. Comparison of the ${ }^{1} \mathrm{H}$ - and ${ }^{13} \mathrm{C}$ NMR spectral data of $\mathbf{1}$ with analogous data for the known withanolide, ixocarpalactone A $(\mathbf{5}),{ }^{8)}$ indicated that $\mathbf{1}$ has the same substituent patterns and relative configuration in rings $\mathrm{B}-\mathrm{D}$ and in the lactone ring as $\mathbf{5}$, with the differences being only in the substituents in ring A. The ${ }^{13} \mathrm{C}$-NMR spectrum of 1 exhibited additional signals for a methoxyl group at C-3, a secondary carbon (C-2), and an oxygenated tertiary carbon (C-3) in ring $\mathrm{A}$, instead of the resonances observed for a double bond at C-2 and C-3 in 5. This was confirmed by observed correlations in the two dimensional (2D) NMR spectra $\left[{ }^{1} \mathrm{H}-{ }^{1} \mathrm{H}\right.$ correlation spectroscopy (COSY), ${ }^{1} \mathrm{H}$-detected heteronuclear multiple quantum coherence (HMQC), heteronuclear multiple bond connectivity (HMBC), and rotating frame Overhauser enhancement spectroscopy (ROESY)]. The methoxyl group in $\mathbf{1}$ was located at $\mathrm{C}-3$ as a result of the observed HMBC correlations $\left(\mathrm{OCH}_{3} / \mathrm{C}-3 ; \mathrm{H}-2 / \mathrm{C}-1,-3,-4\right.$, $10 ; \mathrm{H}-4 / \mathrm{C}-2,-3,-5,-10)$.

In order to confirm the orientation of $\mathrm{OH}-4$, the ${ }^{1} \mathrm{H},{ }^{13} \mathrm{C}$, DEPT, ${ }^{1} \mathrm{H}-{ }^{1} \mathrm{H}$ COSY, HMQC, HMBC and ROESY NMR spectra of 1 were recorded in both $\mathrm{C}_{5} \mathrm{D}_{5} \mathrm{~N}$ and $\mathrm{CDCl}_{3}$. Pyridine can interact with hydroxyl groups to form weak hydro-

Table 1. ${ }^{1} \mathrm{H}-\mathrm{NMR}$ Data for Compounds $\mathbf{1}$ and $\mathbf{2}^{a)}$

\begin{tabular}{|c|c|c|c|c|c|c|}
\hline Position & $\mathbf{1}\left(\mathrm{C}_{5} \mathrm{D}_{5} \mathrm{~N}\right)$ & $1\left(\mathrm{CDCl}_{3}\right)$ & $\delta_{\mathrm{CDCl}_{3}}-\delta_{\mathrm{C}_{5} \mathrm{D}_{5} \mathrm{~N}}$ & $2\left(\mathrm{C}_{5} \mathrm{D}_{5} \mathrm{~N}\right)$ & $2\left(\mathrm{CDCl}_{3}\right)$ & $\delta_{\mathrm{CDCl}_{3}}-\delta_{\mathrm{C}_{5} \mathrm{D}_{5} \mathrm{~N}}$ \\
\hline 2 & $3.05^{b)}, 3.21 \mathrm{dd}(7.7,15.5)$ & $\begin{array}{l}2.63 \mathrm{dd}(3.6,15.5) \\
2.90 \mathrm{dd}(7.5,15.5)\end{array}$ & & $\begin{array}{l}2.98 \text { dd }(3.3,15.5) \\
3.14 \text { dd }(7.5,15.5)\end{array}$ & $\begin{array}{l}2.61 \mathrm{dd}(3.6,15.3) \\
2.95 \mathrm{dd}(7.0,15.3)\end{array}$ & \\
\hline 3 & $3.97 \mathrm{~m}$ & 3.67 ddd $(3.0,3.6,7.5)$ & -0.30 & $3.95^{b)}$ & $3.69 \mathrm{~m}$ & -0.26 \\
\hline 4 & $3.95 \mathrm{~d}(2.7)$ & $3.45 \mathrm{~d}(3.0)$ & -0.50 & $3.95^{b)}$ & $3.48 \mathrm{~d}(3.0)$ & -0.47 \\
\hline 6 & 3.45 br s & 3.21 br s & -0.24 & 3.46 br s & 3.22 br s & -0.24 \\
\hline 7 & $\begin{array}{l}1.46 \text { br d (12.9), } \\
2.26 \text { br d }(12.9)\end{array}$ & $\begin{array}{l}1.34 \text { br d (14.9), } \\
2.19 \text { br d (14.9) }\end{array}$ & & $1.45^{b)}, 2.25^{b)}$ & $\begin{array}{l}1.35 \mathrm{~m} \\
2.17 \text { br d (14.8) }\end{array}$ & \\
\hline 8 & $1.71 \mathrm{~m}$ & $1.54 \mathrm{~m}(4.2,10.9)$ & -0.17 & $1.70^{b)}$ & $1.48^{b)}$ & -0.22 \\
\hline 9 & $1.34 \mathrm{dt}(4.4,11.8)$ & $1.11^{b)}$ & -0.23 & $1.41^{b)}$ & $1.16^{b)}$ & -0.25 \\
\hline 11 & $2.32-2.46 \mathrm{~m}$ & $1.45 \mathrm{dd}(2.5,13.5), 1.28^{b)}$ & & $1.51^{b)}, 1.71^{b)}$ & $1.26^{b)}, 1.41^{b)}$ & \\
\hline 12 & $\begin{array}{l}1.03 \text { brt }(12.7), \\
2.15 \text { br d }(12.7)\end{array}$ & $1.11^{b)}, 2.10 \operatorname{td}(3.0,12.5)$ & & $1.26^{b)}, 2.65$ br d (12.6) & $1.10 \mathrm{~m}, 2.07$ br d (12.3) & \\
\hline 14 & $0.77 \mathrm{~m}$ & $0.85 \mathrm{~m}$ & +0.08 & $0.83 \mathrm{~m}$ & $0.90 \mathrm{~m}$ & +0.07 \\
\hline 15 & $1.54-1.64^{b)}$ & $1.39^{b)}, 2.31^{b)}$ & & $1.41^{b)}, 2.25^{b)}$ & $1.33^{b)}, 2.20 \mathrm{~m}$ & \\
\hline 16 & $4.80 \mathrm{~m}$ & $4.45 \mathrm{~m}$ & -0.35 & $4.71 \mathrm{~m}$ & $4.49 \mathrm{~m}$ & -0.22 \\
\hline 17 & $1.57 \mathrm{~d}(7.3)$ & $1.33^{b)}$ & -0.24 & $1.68^{b)}$ & $1.49^{b)}$ & -0.19 \\
\hline 18 & $1.43 \mathrm{~s}$ & $1.11 \mathrm{~s}$ & -0.32 & $1.26 \mathrm{~s}$ & $1.02 \mathrm{~s}$ & -0.24 \\
\hline 19 & $1.74 \mathrm{~s}$ & $1.29 \mathrm{~s}$ & -0.45 & $1.78 \mathrm{~s}$ & $1.29 \mathrm{~s}$ & -0.49 \\
\hline 21 & $1.74 \mathrm{~s}$ & $1.30 \mathrm{~s}$ & -0.44 & $1.95 \mathrm{~s}$ & $1.47 \mathrm{~s}$ & -0.48 \\
\hline 22 & $4.59 \mathrm{~s}$ & $4.04 \mathrm{~s}$ & -0.55 & 4.61 br s & 4.14 br s & -0.47 \\
\hline 23 & $4.93 \mathrm{~d}(8.3)$ & $4.49 \mathrm{~d}(8.4)$ & -0.44 & & & \\
\hline 24 & $2.32-2.46^{b)}$ & $2.33 \mathrm{~m}(7.1)$ & & $2.21^{b)}$ & $2.01^{b)}$ & -0.20 \\
\hline 25 & $3.05^{b)}$ & $2.69 \mathrm{~m}(7.1)$ & -0.36 & $3.10 \mathrm{~m}$ & $2.65 \mathrm{~m}(7.0)$ & -0.45 \\
\hline 27 & $1.20 \mathrm{~d}(7.1)$ & $1.17 \mathrm{~d}(7.1)$ & -0.03 & $1.23 \mathrm{~d}(7.0)$ & $1.18 \mathrm{~d}(7.0)$ & -0.05 \\
\hline 28 & $1.21 \mathrm{~d}(7.1)$ & $1.25 \mathrm{~d}(6.8)$ & +0.04 & $1.33 \mathrm{~d}(7.0)$ & $1.20 \mathrm{~d}(7.0)$ & -0.13 \\
\hline $\mathrm{OCH}_{3}-3$ & $3.36 \mathrm{~s}$ & $3.36 \mathrm{~s}$ & 0 & $3.36 \mathrm{~s}$ & $3.35 \mathrm{~s}$ & -0.01 \\
\hline $\mathrm{OH}-4$ & $7.98 \mathrm{~s}$ & & & & & \\
\hline OH-16 & $7.81 \mathrm{~d}(2.9)$ & & & & & \\
\hline OH-20 & $6.21 \mathrm{~s}$ & & & & & \\
\hline $\mathrm{OH}-22$ & $6.00 \mathrm{~s}$ & & & & & \\
\hline
\end{tabular}
signals. 
gen bonds and collision complexes, and thereby produces shielding and deshielding cones and influences the chemical shift of the neighboring protons. ${ }^{8,9)}$ The shift differences observed in different solvents are then used to determine the position and orientation of hydroxyl groups. ${ }^{8,9)}$ A difference of the ${ }^{1} \mathrm{H}-\mathrm{NMR}$ chemical shift $\left(\Delta=\delta_{\mathrm{CDCl}_{3}}-\delta_{\mathrm{C}_{5} \mathrm{D}_{5} \mathrm{~N}}\right)$ (Table 1$)$ of the most diagnostic signal was found for $\mathrm{CH}_{3}-19(\Delta=$ $-0.45)$, which suggested that both $\mathrm{OH}-4$ and $\mathrm{CH}_{3}-19$ have a $\beta$-orientation in $\mathbf{1}$. Additionally, the relative stereochemistry at $\mathrm{H}-3 \alpha$ and $\mathrm{H}-4 \alpha$ was confirmed by the observed coupling constant values in $\mathrm{CDCl}_{3}\left(J_{2 \alpha, 3 \alpha}=3.6 \mathrm{~Hz}, J_{2 \beta, 3 \alpha}=7.5 \mathrm{~Hz}\right.$, $J_{3 \alpha, 4 \alpha}=3.0 \mathrm{~Hz}$ ), and the observed ROESY correlations ( $\mathrm{H}-$ $2 \alpha / \mathrm{H}-3 \alpha ; \mathrm{H}-4 \alpha / \mathrm{H}-6 \alpha)$. The absolute configurations of the stereogenic centers at C-3 and C-4 in 1 were both assigned as $S$ from circular dichroism (CD) spectroscopic evidence. It was previously reported that the $4 \beta$-hydroxy- $5 \beta, 6 \beta$-epoxy- 1 one structure of withanolides gives a strong negative Cotton effect at $290 \mathrm{~nm}$ based on the $n \rightarrow \pi^{*}$ transition of the nonconjugated ketone. $^{21)}$ The identical CD spectrum of $\mathbf{1}\left(\Delta \varepsilon_{290}\right.$ $-21027)$ to that of $(20 R, 22 R, 24 S, 25 R)-4 \beta, 20 \beta$-dihydroxy$5 \beta, 6 \beta$-epoxy-3 $\beta$-methoxy-1-oxowithanolide $\left(\Delta \varepsilon_{290}-15100\right)$ indicated that the absolute configuration of the ring $\mathrm{A} / \mathrm{B}$ part of 1 was the same as that of the latter compound. ${ }^{21)}$ In this manner, compound $\mathbf{1}$ was assigned as 2,3-dihydro-3 $\beta$ methoxyixocarpalactone A.

Compound 2 was obtained as a white amorphous powder, with mp $190-192^{\circ} \mathrm{C}$ and $[\alpha]_{\mathrm{D}}^{20}-117^{\circ}\left(c=0.076, \mathrm{CH}_{3} \mathrm{CN}\right)$. The molecular formula of $\mathbf{2}$ was determined to be $\mathrm{C}_{29} \mathrm{H}_{42} \mathrm{O}_{9}$ based on HR-MS $\left(m / z 535.2931[\mathrm{M}+\mathrm{H}]^{+}\right)$. Both the ${ }^{1} \mathrm{H}$ - and ${ }^{13} \mathrm{C}$-NMR spectral data of compound 2 (Tables 1,3 ) were very similar to those of the withanolide, ixocarpalactone B, which was obtained in our previous work on P. philadelphica aerial parts, ${ }^{8)}$ but differences were evident between these substances in terms of the ring A substituents. In the ${ }^{1} \mathrm{H}-\mathrm{NMR}$ spectrum of 2, four methyl singlets and two methyl doublets were apparent. The ${ }^{13} \mathrm{C}$-NMR spectrum in $\mathrm{CDCl}_{3}$ of $\mathbf{2}$ exhibited additional signals for an additional methoxyl group $\left(\delta_{\mathrm{C}}\right.$ $56.9)$, a secondary carbon $\left[\delta_{\mathrm{C}} 39.9(\mathrm{C}-2)\right]$, and an oxygenated tertiary carbon $\left[\delta_{\mathrm{C}} 77.1(\mathrm{C}-3)\right]$ in ring $\mathrm{A}$, but minus the resonances for a double bond at $\mathrm{C}-2$ and $\mathrm{C}-3$, when compared to ixocarpalactone B. The methoxyl group in $\mathbf{2}$ was located at $\mathrm{C}-3$ as a result of the observed HMBC correlations $\left(\mathrm{OC}_{3} / \mathrm{C}-3\right.$; H-2/C-1, -3, -4, -10; H-4/C-2, -3, -5, -6, -10). A pyridine-induced shift $\left(\Delta=\delta_{\mathrm{CDCl}_{3}}-\delta_{\mathrm{C}_{5} \mathrm{D}_{5} \mathrm{~N}}\right)$ experiment for compound 2 (Table 1) gave analogous results to those obtained for 1, and indicated that $\mathrm{OH}-4$ also has a $\beta$-orientation. The relative stereochemistry of $\mathrm{H}-3 \alpha$ and $\mathrm{H}-4 \alpha$ in 2 was also confirmed by the similar $J$ values and ROESY correlations, as observed for the ring A moiety of $\mathbf{1}$. The similar CD spectrum of $2(\Delta \varepsilon-17992)$ at $290 \mathrm{~nm}$ to that observed for 1 indicated that the absolute configuration of the AB-ring portion of $\mathbf{2}$ was the same as that of $\mathbf{1}$. Hence, compound $\mathbf{2}$ was determined to be 2,3-dihydro-3 $\beta$-methoxyixocarpalactone $\mathrm{B}$.

A molecular formula of $\mathrm{C}_{28} \mathrm{H}_{40} \mathrm{O}_{8}$ was determined for 3 based on HR-MS $\left(m / z 505.2816[\mathrm{M}+\mathrm{H}]^{+}\right)$. Comparison of the ${ }^{1} \mathrm{H}$ - and ${ }^{13} \mathrm{C}$-NMR spectral data of $\mathbf{3}$ (Tables 2, 3) with those of ixocarpalactone $\mathrm{B},{ }^{8}$ indicated that compound 3 possesses a non-conjugated ketone $\left[\delta_{\mathrm{C}} 212.0(\mathrm{~s}, \mathrm{C}-1)\right]$, instead of an $\alpha, \beta$-unsaturated ketone. The relative stereochemistry of $\mathrm{OH}-4 \beta$ was confirmed by the pyridine-induced shift $(\Delta=$ $\left.\delta_{\mathrm{CDCl}_{3}}-\delta_{\mathrm{C}_{5} \mathrm{D}_{5} \mathrm{~N}}\right)$ for $\mathrm{CH}_{3}-19(\Delta=-0.47)$ (Table 2$)$, and the observed ROESY correlations between $\mathrm{H}-4 \alpha$ and $\mathrm{H}-6 \alpha$. The absolute configuration of C-4 of $\mathbf{3}$ was established as $S$ as a result of the observed negative Cotton effect $(\Delta \varepsilon-9840)$ at $295 \mathrm{~nm}$ from a CD experiment. Thus, compound 3 was assigned as 2,3-dihydroixocarpalactone $\mathrm{B}$.

Compound 4, $[\alpha]_{\mathrm{D}}^{20}-26^{\circ}\left(c=0.082, \mathrm{CH}_{3} \mathrm{CN}\right)$, was obtained as an amorphous solid. The molecular formula was determined to be $\mathrm{C}_{28} \mathrm{H}_{40} \mathrm{O}_{6}$ based on HR-MS (obsd $\mathrm{m} / \mathrm{z} 495.2757$

Table 2. ${ }^{1} \mathrm{H}-\mathrm{NMR}$ Data for Compounds $\mathbf{3}$ and $\mathbf{4}^{a)}$

\begin{tabular}{|c|c|c|c|c|c|c|}
\hline Position & $3\left(\mathrm{C}_{5} \mathrm{D}_{5} \mathrm{~N}\right)$ & $3\left(\mathrm{CDCl}_{3}\right)$ & $\delta_{\mathrm{CDCl}_{3}}-\delta_{\mathrm{C}_{5} \mathrm{D}_{5} \mathrm{~N}}$ & $4\left(\mathrm{C}_{5} \mathrm{D}_{5} \mathrm{~N}\right)$ & $4\left(\mathrm{CDCl}_{3}\right)$ & $\delta_{\mathrm{CDCl}_{3}}-\delta_{\mathrm{C}_{5} \mathrm{D}_{5} \mathrm{~N}}$ \\
\hline 2 & $2.67^{b)}, 2.83$, ddd $(5.0,5.516 .3)$ & $2.51-2.60 \mathrm{~m}$ & & $6.08 \mathrm{~d}(9.9)$ & $6.00 \mathrm{~d}(10.0)$ & -0.08 \\
\hline 3 & $2.18 \mathrm{~m}$ & $2.02-2.12 \mathrm{~m}$ & & $7.04 \mathrm{dd}(4.4,9.9)$ & $6.79 \mathrm{dd}(4.4,10.0)$ & -0.25 \\
\hline 4 & 3.80 brt (2.7) & $3.50 \mathrm{dd}(3.1,3.4)$ & -0.30 & $4.97 \mathrm{~d}(4.4)$ & $4.69 \mathrm{~d}(4.4)$ & -0.28 \\
\hline 6 & $3.24 \mathrm{brs}$ & $3.13 \mathrm{brs}$ & -0.11 & $6.43 \mathrm{~d}(5.4)$ & $6.12 \mathrm{~d}(5.5)$ & -0.31 \\
\hline 7 & $1.45^{b)}, 2.25^{b)}$ & $1.29-1.39^{b)}, 2.19^{b)}$ & & $4.20 \mathrm{dd}(5.4,5.4)$ & $3.98 \mathrm{dd}(5.5,5.5)$ & -0.22 \\
\hline 8 & $1.69^{b)}$ & $1.51 \mathrm{~m}$ & -0.18 & $1.68^{b)}$ & $1.55^{b)}$ & -0.13 \\
\hline 9 & $1.28^{b)}$ & $1.07-1.12^{b)}$ & & $2.52^{b)}$ & $1.88^{b)}$ & -0.64 \\
\hline 11 & $1.69^{b)}, 1.48^{b)}$ & $1.42 \mathrm{~m}, 1.23^{b)}$ & & $1.75^{b)}, 2.41^{b)}$ & $1.60^{b)}, 2.00^{b)}$ & \\
\hline 12 & $1.20^{b)}, 2.65^{b)}$ & $1.07-1.12^{b)}, 2.02-2.12^{b)}$ & & $1.52^{b)}, 2.17^{b)}$ & $2.05^{b)}, 2.15^{b)}$ & \\
\hline 14 & $0.92 \mathrm{~m}$ & $0.87 \mathrm{~m}$ & -0.05 & $2.09^{b)}$ & $1.52^{b)}$ & -0.57 \\
\hline 15 & $1.41^{b)}, 2.27^{b)}$ & $1.29-1.39^{b)}, 2.20^{b)}$ & & $2.58^{b)}$ & $1.30^{b)}, 1.80^{b)}$ & \\
\hline 16 & $4.71 \mathrm{~m}(3.0)$ & $4.48 \mathrm{~m}$ & -0.23 & $2.22^{b)}$ & $1.42^{b)}, 2.22^{b)}$ & \\
\hline 17 & $1.69 \mathrm{~d}(5.8)$ & $1.48 \mathrm{~d}(6.1)$ & -0.21 & $1.72^{b)}$ & $1.50^{b)}$ & -0.22 \\
\hline 18 & $1.25 \mathrm{~s}$ & $1.01 \mathrm{~s}$ & -0.24 & $1.25 \mathrm{~s}$ & $0.93 \mathrm{~s}$ & -0.32 \\
\hline 19 & $1.76 \mathrm{~s}$ & $1.29 \mathrm{~s}$ & -0.47 & $1.79 \mathrm{~s}$ & $1.45 \mathrm{~s}$ & -0.34 \\
\hline 21 & $1.94 \mathrm{~s}$ & $1.47 \mathrm{~s}$ & -0.47 & $1.46 \mathrm{~s}$ & $1.30 \mathrm{~s}$ & -0.16 \\
\hline 22 & $4.61 \mathrm{brs}$ & 4.14 br s & -0.47 & 4.43 br d (10.0) & $4.19 \mathrm{dd}(2.0,10.0)$ & -0.24 \\
\hline 23 & & & & $1.41^{b)}, 1.57^{b)}$ & $1.50^{b)}, 1.75^{b)}$ & \\
\hline 24 & $2.23^{b)}$ & $2.02 \mathrm{dq}(7.1)$ & -0.21 & $1.82^{b)}$ & $1.82^{b)}$ & 0 \\
\hline 25 & $3.09 \mathrm{dq}(7.1)$ & $2.64 \mathrm{dq}(7.1)$ & -0.45 & $2.17^{b)}$ & $2.15^{b)}$ & -0.02 \\
\hline 27 & $1.23 \mathrm{~d}(7.1)$ & $1.17 \mathrm{~d}(7.1)$ & -0.06 & $1.22 \mathrm{~d}(6.6)$ & $1.23 \mathrm{~d}(6.6)$ & +0.01 \\
\hline 28 & $1.33 \mathrm{~d}(7.0)$ & $1.19 \mathrm{~d}(7.0)$ & -0.14 & $1.00 \mathrm{~d}(6.7)$ & $1.15 \mathrm{~d}(6.6)$ & +0.15 \\
\hline $\mathrm{OH}-22$ & & 2.76 brs & & & & \\
\hline
\end{tabular}

a) Spectra taken at $500 \mathrm{MHz}$; chemical shift values presented in ppm; $J$ values in parentheses given in Hz; TMS used as internal standard. b) Overlapped with other proton signals. 
Table $3 .{ }^{13}$ C-NMR Spectra Data for Compounds $\mathbf{1}-\mathbf{4}^{a)}$

\begin{tabular}{|c|c|c|c|c|c|c|c|c|}
\hline Position & $\mathbf{1}^{b)}$ & $\mathbf{1}^{c)}$ & $\mathbf{2}^{b)}$ & $\mathbf{2}^{c)}$ & $\mathbf{3}^{b)}$ & $\mathbf{3}^{c)}$ & $4^{b)}$ & $4^{c)}$ \\
\hline 1 & $210.7 \mathrm{~s}$ & $210.9 \mathrm{~s}$ & $209.6 \mathrm{~s}$ & $210.5 \mathrm{~s}$ & $211.0 \mathrm{~s}$ & $212.0 \mathrm{~s}$ & $203.4 \mathrm{~s}$ & $202.1 \mathrm{~s}$ \\
\hline 2 & $42.3 \mathrm{t}$ & $40.2 \mathrm{t}$ & $41.2 \mathrm{t}$ & $39.9 \mathrm{t}$ & $32.0 \mathrm{t}$ & $31.6 \mathrm{t}$ & $128.5 \mathrm{~d}$ & $129.3 \mathrm{~d}$ \\
\hline 3 & $80.1 \mathrm{~d}$ & $77.8 \mathrm{~d}$ & $78.8 \mathrm{~d}$ & $77.1 \mathrm{~d}$ & $27.0 \mathrm{t}$ & $26.1 \mathrm{t}$ & $146.0 \mathrm{~d}$ & $142.4 \mathrm{~d}$ \\
\hline 4 & $75.9 \mathrm{~d}$ & $74.5 \mathrm{~d}$ & $74.7 \mathrm{~d}$ & $74.5 \mathrm{~d}$ & $73.0 \mathrm{~d}$ & $72.8 \mathrm{~d}$ & $69.2 \mathrm{~d}$ & $69.1 \mathrm{~d}$ \\
\hline 5 & $66.4 \mathrm{~s}$ & $65.0 \mathrm{~s}$ & $65.2 \mathrm{~s}$ & $65.1 \mathrm{~s}$ & $67.4 \mathrm{~s}$ & $66.8 \mathrm{~s}$ & $142.0 \mathrm{~s}$ & $143.0 \mathrm{~s}$ \\
\hline 6 & $59.3 \mathrm{~d}$ & $58.9 \mathrm{~d}$ & $58.0 \mathrm{~d}$ & $59.2 \mathrm{~d}$ & $57.1 \mathrm{~d}$ & $58.4 \mathrm{~d}$ & $132.5 \mathrm{~d}$ & $131.4 \mathrm{~d}$ \\
\hline 7 & $33.0 \mathrm{t}$ & $31.2 \mathrm{t}$ & $31.8 \mathrm{t}$ & $30.9 \mathrm{t}$ & $31.9 \mathrm{t}$ & $31.3 \mathrm{t}$ & $64.1 \mathrm{~d}$ & $64.4 \mathrm{~d}$ \\
\hline 8 & $30.5 \mathrm{~d}$ & $28.8 \mathrm{~d}$ & $29.5 \mathrm{~d}$ & $28.7 \mathrm{~d}$ & $29.6 \mathrm{~d}$ & $28.8 \mathrm{~d}$ & $38.3 \mathrm{~d}$ & $37.2 \mathrm{~d}$ \\
\hline 9 & $44.5 \mathrm{~d}$ & $43.0 \mathrm{~d}$ & $43.3 \mathrm{~d}$ & $42.8 \mathrm{~d}$ & $43.8 \mathrm{~d}$ & $43.3 \mathrm{~d}$ & $36.2 \mathrm{~d}$ & $35.0 \mathrm{~d}$ \\
\hline 10 & $52.2 \mathrm{~s}$ & $50.7 \mathrm{~s}$ & $51.1 \mathrm{~s}$ & $50.4 \mathrm{~s}$ & $51.1 \mathrm{~s}$ & $50.6 \mathrm{~s}$ & $50.7 \mathrm{~s}$ & $50.0 \mathrm{~s}$ \\
\hline 11 & $22.6 \mathrm{t}$ & $21.0 \mathrm{t}$ & $21.2 \mathrm{t}$ & $20.6 \mathrm{t}$ & $21.2 \mathrm{t}$ & $20.8 \mathrm{t}$ & $22.4 \mathrm{t}$ & $21.7 \mathrm{t}$ \\
\hline 12 & $41.2 \mathrm{t}$ & $39.8 \mathrm{t}$ & $40.0 \mathrm{t}$ & $39.1 \mathrm{t}$ & $40.1 \mathrm{t}$ & $39.3 \mathrm{t}$ & $40.6 \mathrm{t}$ & $39.7 \mathrm{t}$ \\
\hline 13 & $44.9 \mathrm{~s}$ & $43.4 \mathrm{~s}$ & $43.4 \mathrm{~s}$ & $42.7 \mathrm{~s}$ & $43.4 \mathrm{~s}$ & $42.9 \mathrm{~s}$ & $43.2 \mathrm{~s}$ & $42.9 \mathrm{~s}$ \\
\hline 14 & $58.0 \mathrm{~d}$ & $54.5 \mathrm{~d}$ & $54.5 \mathrm{~d}$ & $54.2 \mathrm{~d}$ & $54.6 \mathrm{~d}$ & $54.5 \mathrm{~d}$ & $50.8 \mathrm{~d}$ & $50.0 \mathrm{~d}$ \\
\hline 15 & $39.3 \mathrm{t}$ & $37.1 \mathrm{t}$ & $34.2 \mathrm{t}$ & $33.5 \mathrm{t}$ & $34.0 \mathrm{t}$ & $33.6 \mathrm{t}$ & $23.5 \mathrm{t}$ & $23.8 \mathrm{t}$ \\
\hline 16 & $73.8 \mathrm{~d}$ & $72.8 \mathrm{~d}$ & $75.6 \mathrm{~d}$ & $75.1 \mathrm{~d}$ & $75.7 \mathrm{~d}$ & $75.1 \mathrm{~d}$ & $24.5 \mathrm{t}$ & $22.6 \mathrm{t}$ \\
\hline 17 & $59.3 \mathrm{~d}$ & $57.4 \mathrm{~d}$ & $63.5 \mathrm{~d}$ & $62.3 \mathrm{~d}$ & $63.5 \mathrm{~d}$ & $62.4 \mathrm{~d}$ & $55.5 \mathrm{~d}$ & $55.4 \mathrm{~d}$ \\
\hline 18 & $16.2 \mathrm{q}$ & $14.5 \mathrm{q}$ & $15.2 \mathrm{q}$ & $14.7 \mathrm{q}$ & $15.1 \mathrm{q}$ & $14.8 \mathrm{q}$ & $14.3 \mathrm{q}$ & $13.4 \mathrm{q}$ \\
\hline 19 & $16.7 \mathrm{q}$ & $14.8 \mathrm{q}$ & $15.4 \mathrm{q}$ & $15.0 \mathrm{q}$ & $15.4 \mathrm{q}$ & $15.2 \mathrm{q}$ & $21.8 \mathrm{q}$ & $21.7 \mathrm{q}$ \\
\hline 20 & $80.9 \mathrm{~s}$ & $79.4 \mathrm{~s}$ & $74.3 \mathrm{~s}$ & $74.7 \mathrm{~s}$ & $74.3 \mathrm{~s}$ & $74.8 \mathrm{~s}$ & $75.2 \mathrm{~s}$ & $75.5 \mathrm{~s}$ \\
\hline 21 & $24.0 \mathrm{q}$ & $21.9 \mathrm{q}$ & $27.3 \mathrm{q}$ & $26.6 \mathrm{q}$ & $27.2 \mathrm{q}$ & $26.9 \mathrm{q}$ & $21.0 \mathrm{q}$ & $20.7 \mathrm{q}$ \\
\hline 22 & $75.2 \mathrm{~d}$ & $73.1 \mathrm{~d}$ & $72.1 \mathrm{~d}$ & $71.5 \mathrm{~d}$ & $72.1 \mathrm{~d}$ & $71.8 \mathrm{~d}$ & $81.2 \mathrm{~d}$ & $80.4 \mathrm{~d}$ \\
\hline 23 & $80.6 \mathrm{~d}$ & $79.0 \mathrm{~d}$ & $109.0 \mathrm{~s}$ & $108.0 \mathrm{~s}$ & $109.0 \mathrm{~s}$ & $107.7 \mathrm{~s}$ & $31.8 \mathrm{t}$ & $31.2 \mathrm{t}$ \\
\hline 24 & $43.6 \mathrm{~d}$ & $42.0 \mathrm{~d}$ & $50.2 \mathrm{~d}$ & $49.2 \mathrm{~d}$ & $50.2 \mathrm{~d}$ & $49.3 \mathrm{~d}$ & $31.8 \mathrm{~d}$ & $31.3 \mathrm{~d}$ \\
\hline 25 & $41.9 \mathrm{~d}$ & $40.3 \mathrm{~d}$ & $43.5 \mathrm{~d}$ & $42.4 \mathrm{~d}$ & $43.3 \mathrm{~d}$ & $42.4 \mathrm{~d}$ & $40.4 \mathrm{~d}$ & $40.5 \mathrm{~d}$ \\
\hline 26 & $181.8 \mathrm{~s}$ & $181.7 \mathrm{~s}$ & $177.8 \mathrm{~s}$ & $178.1 \mathrm{~s}$ & $177.8 \mathrm{~s}$ & $177.8 \mathrm{~s}$ & $176.2 \mathrm{~s}$ & $176.0 \mathrm{~s}$ \\
\hline 27 & $15.8 \mathrm{q}$ & $14.1 \mathrm{q}$ & $14.5 \mathrm{q}$ & $13.9 \mathrm{q}$ & $14.5 \mathrm{q}$ & $13.9 \mathrm{q}$ & $14.5 \mathrm{q}$ & $14.2 \mathrm{q}$ \\
\hline 28 & $14.4 \mathrm{q}$ & $12.9 \mathrm{q}$ & $12.3 \mathrm{q}$ & $12.0 \mathrm{q}$ & $12.3 \mathrm{q}$ & $12.1 \mathrm{q}$ & $21.1 \mathrm{q}$ & $21.4 \mathrm{q}$ \\
\hline $\mathrm{OCH}_{3}-3$ & $55.9 \mathrm{q}$ & $57.0 \mathrm{q}$ & $56.8 \mathrm{q}$ & $56.9 \mathrm{q}$ & & & & \\
\hline
\end{tabular}

a) TMS was used as internal standard; the data of compounds $\mathbf{1}$ and $\mathbf{2}$ were obtained at $90 \mathrm{MHz}$, while the spectra of $\mathbf{3}$ and $\mathbf{4}$ were taken at $125 \mathrm{MHz}$; all data were assigned based on their ${ }^{1} \mathrm{H}-{ }^{1} \mathrm{H}$ COSY, HMQC and HMBC spectra. b) $\mathrm{C}_{5} \mathrm{D}_{5} \mathrm{~N}$ was used as solvent. c) $\mathrm{CDCl}_{3}$ was used as solvent.

$[\mathrm{M}+\mathrm{Na}]^{+}$). The ${ }^{1} \mathrm{H}-\mathrm{NMR}$ spectrum (in $\mathrm{CDCl}_{3}$ ) of compound 4 (Table 2) displayed characteristic signals for five methyl groups $\left[\delta_{\mathrm{H}} 0.93\left(3 \mathrm{H}, \mathrm{s}, \mathrm{CH}_{3}-18\right), 1.15(3 \mathrm{H}, \mathrm{d}, J=6.6 \mathrm{~Hz}\right.$, $\left.\mathrm{CH}_{3}-28\right), 1.23\left(3 \mathrm{H}, \mathrm{d}, J=6.6 \mathrm{~Hz}, \mathrm{CH}_{3}-27\right), 1.30\left(3 \mathrm{H}, \mathrm{s}, \mathrm{CH}_{3}-\right.$ 21), $\left.1.45\left(3 \mathrm{H}, \mathrm{s}, \mathrm{CH}_{3}-19\right)\right]$, and a pair of $\alpha, \beta$-unsaturated olefinic protons $\left[\delta_{\mathrm{H}} 6.00(1 \mathrm{H}, \mathrm{d}, J=10.0 \mathrm{~Hz}, \mathrm{H}-2), 6.79(1 \mathrm{H}\right.$, $\mathrm{dd}, J=4.4,10.0 \mathrm{~Hz}, \mathrm{H}-3)]$, and an additional olefinic proton $\left[\delta_{\mathrm{H}} 6.12(1 \mathrm{H}, \mathrm{d}, J=5.5 \mathrm{~Hz}, \mathrm{H}-6)\right]$. In the ${ }^{1} \mathrm{H}-{ }^{1} \mathrm{H}$ COSY spectrum of $4, \mathrm{H}-3$ correlated to $\mathrm{H}-2$ and the oxygenated methine proton at $\delta_{\mathrm{H}} 4.69(1 \mathrm{H}, \mathrm{d}, J=4.4 \mathrm{~Hz}, \mathrm{H}-4)$, and indicated the presence of a $4 \beta$-hydroxy-2-en-1-one unit in the molecule. The ${ }^{13} \mathrm{C}$-NMR and DEPT spectra (in $\mathrm{CDCl}_{3}$ ) of 4 (Table 3 ) disclosed 28 carbons, which were indicative of an $\alpha, \beta$-unsaturated ketone $\left[\delta_{\mathrm{C}} 202.1(\mathrm{C}-1), 129.3(\mathrm{C}-2), 142.4(\mathrm{C}-3)\right]$, a further double bond $\left[\delta_{\mathrm{C}} 131.4(\mathrm{C}-6), 143.0(\mathrm{C}-5)\right]$, a $\delta$-lactone carbonyl $\left[\delta_{\mathrm{C}} 176.0(\mathrm{C}-26)\right]$, three oxygenated methines $\left[\delta_{\mathrm{C}} 64.4(\mathrm{C}-7), 69.1(\mathrm{C}-4), 80.4(\mathrm{C}-22)\right]$, one oxygenated quaternary carbon $\left[\delta_{\mathrm{C}} 75.5(\mathrm{C}-20)\right]$, as well as an additional five methyls, five methylenes, six methines, and two quaternary carbons. These NMR data were closely comparable to those of the recently reported withanolide, philadelphicalactone $\mathrm{A},{ }^{8)}$ and suggested that compound $\mathbf{4}$ is also a withanolide. Comparison of the ${ }^{1} \mathrm{H}$ - and ${ }^{13} \mathrm{C}-\mathrm{NMR}$ spectral data (Tables 2, 3) of 4 with analogous data of philadelphicalactone $\mathrm{A}$ indicated that compound $\mathbf{4}$ exhibited additional signals for a double bond between C-5 and C-6, an oxygenated methine at $\mathrm{C}-7$, and another methine at $\mathrm{C}-17$, instead of the resonances observed for an epoxide group, a methylene, and an oxygenated quaternary carbon in the latter compound, respectively. One double bond was located at C-5 and C-6 as a re- sult of the observed HMBC correlations (H-3/C-1, -5; H$4 / \mathrm{C}-3,-6,-10 ; \mathrm{H}-6 / \mathrm{C}-4,-7,-8,10)$. The fact that one hydroxyl group in 4 was translocated from $\mathrm{C}-17$ to $\mathrm{C}-7$ as compared to philadelphicalactone $\mathrm{A}$ was evidenced by the observed ${ }^{1} \mathrm{H}-{ }^{1} \mathrm{H}$ COSY correlations $(\mathrm{H}-7 / \mathrm{H}-6,-8)$ and HMBC correlations (H-6/C-4, -7, -8, -10; H-7/C-5) in 4, as well as the decreased pyridine-induced shift effect $(\Delta=-0.24)$ of $\mathrm{H}$ 22 in 4 as compared to the shift $(\Delta=-0.63)$ in the latter compound. $^{22)}$ The relative stereochemistry of $\mathrm{H}-4 \alpha$ and $\mathrm{H}-$ $7 \alpha$ was confirmed by the observed coupling constant values in $\mathrm{CDCl}_{3}\left(J_{3,4 \alpha}=4.4 \mathrm{~Hz}, J_{6,7 \alpha}=5.5 \mathrm{~Hz}, J_{7 \alpha, 8 \beta}=5.5 \mathrm{~Hz}\right)$, and the observed ROESY correlations (H-6/H- $4 \alpha,-7 \alpha$; H-7 $\alpha / \mathrm{H}-$ $6,-9 \alpha)$. Thus, compound 4 was elucidated as $4 \beta, 7 \beta, 20 R$-trihydroxy-1-oxowitha-2,5-dien-22,26-olide.

Isolates 1-4 obtained from the leaves and stems of $P$. philadelphica were evaluated for their potential to induce quinone reductase $(\mathrm{QR})$ activity in murine Hepa 1c1c7 hepatoma cells. ${ }^{7,13)}$ The results (Table 4) showed that compounds 3 and 4 significantly induced QR activity, with observed concentrations to double induction (CD) values of 3.81 and $1.12 \mu \mathrm{M}$, while compounds $\mathbf{1}$ and $\mathbf{2}$ were not regarded as active $(\mathrm{CD}>10 \mu \mathrm{M})$. These results support the previously proposed structure-activity relationships for withanolides, in that the presence of $4 \beta$-hydroxy-2-en-1-one and/or $5 \beta, 6 \beta$-epoxy units in the withanolides is associated with quinone reductase-inducing activity. ${ }^{8)}$ Ixocarpalactone A (5) has been selected for ongoing in vivo biological testing in our program of research on naturally occurring cancer chemopreventive agents due to its relatively high content in the leaves and stems of $P$. philadelphica and its promising in vitro activ- 
ities (e.g., induction of quinone reductase; inhibition of JB6 cell transformation). ${ }^{8)}$ This compound is included in Table 4 for comparison purposes. Sulforaphane was used as a positive control substance. ${ }^{7)}$

In order to determine if compounds $\mathbf{1}$ and $\mathbf{2}$ are artifactual in nature, two sample solutions were prepared by extracting the dried and milled leaves and stems of $P$. philadelphica with $\mathrm{MeOH}$ and $\mathrm{CH}_{3} \mathrm{CN}$, respectively, and then subjecting them to LC-MS-MS analysis, as described in the Experimental Section. Tandem mass spectrometric analysis of $\mathbf{1}$ and $\mathbf{2}$ was carried out to select pairs of precursor/product ions for multiple reaction monitoring (MRM) during LC-MS-MS. The collision-induced dissociation (CID) product ion tandem mass spectra of the $[\mathrm{M}+\mathrm{H}]^{+}$ions of $m / z 537$ (1) and 535 (2) are shown in Fig. 2. The presence of abundant fragment ions of $\mathbf{1}$ and $\mathbf{2}$ provided many choices for their selective detec-

Table 4. Induction of Quinone Reductase (QR) Activity by Withanolides $(\mathbf{1}-\mathbf{5})^{a)}$

\begin{tabular}{cccc}
\hline \hline Compound & $\mathrm{CD} \pm$ S.D. $(\mu \mathrm{M})$ & $\mathrm{IC}_{50} \pm$ S.D. $(\mu \mathrm{M})$ & $\mathrm{CI}$ \\
\hline $\mathbf{1}$ & $18.63 \pm 4.29$ & $>20$ & n.c. $^{b)}$ \\
$\mathbf{3}$ & $10.15 \pm 4.18$ & $106.6 \pm 0.2$ & 10 \\
$\mathbf{4}$ & $3.81 \pm 1.47$ & $96.9 \pm 2.4$ & 20 \\
Ixocarpalactone A (5) $_{\text {Sulforaphane }^{c)}}$ & $0.22 \pm 0.08$ & $23.9 \pm 5.2$ & 21 \\
& $0.36 \pm 0.17$ & $4.1 \pm 2.9$ & 19 \\
& & $9.9 \pm 2.1$ & 28
\end{tabular}

a) QR activity was determined with murine Hepa 1c1c7 cells as described in the Experimental Section. $\mathrm{CD}$, concentration required to double $\mathrm{QR}$ activity; $\mathrm{IC}_{50}$, concentration to inhibit cell viability by $50 \%$; CI, chemopreventive index $\left(\mathrm{IC}_{50} / \mathrm{CD}\right)$ (expressed to nearest whole number). b) Not calculated. c) Positive control. tion during LC-MS-MS analysis of the complex crude plant extract. Precursor/product ion pairs selected for MRM in LCMS-MS analysis are listed in Table 5. Optimized collision energy and electrospray cone voltage, parameters which affect additional internal energy input into precursor ions within the ion source, as well as the transmission of ions for each of the MRM channels, are also listed in Table 5. The fragment ions chosen in Table 5 were among the most abundant observed (Fig. 2) and represent structural characteristics of each compound of interest. Standards $\mathbf{1}$ and $\mathbf{2}$ were mixed and analyzed by LC-MS-MS using these optimized MRM conditions (Table 5). A typical LC-MS-MS MRM chromatogram of the standards over $30 \mathrm{~min}$ is shown in Fig. 3 . MRM channels of $m / z 537 \rightarrow 451,537 \rightarrow 519$, and $537 \rightarrow 501$ were used for the detection of 1 , and $\mathrm{m} / \mathrm{z} 535 \rightarrow 143$, $535 \rightarrow 517$, and $535 \rightarrow 211$ for 2 . The total ion chromatogram (TIC) of these six MRM channels is provided at the bottom of the figure. Under the HPLC separation conditions selected, compounds 1 and $\mathbf{2}$ showed baseline separation (Fig. 3), with retention times of 16.8 and $20.7 \mathrm{~min}$, respectively, and the limit of detection (LOD) was ca. $200 \mathrm{pg}(\mathrm{S} / \mathrm{N}>3)$ for each compound in the mass spectrometer. Two sets of methanolic extracts of the dried leaves and stems of P. philadelphica (ca. $50 \mathrm{mg} / \mathrm{ml}$ ) were analyzed using MRM LC-MS-MS. During the sample preparation and analysis steps, great care was used to prevent cross contamination or sample carry over. An example is shown in Fig. 4. Only compound 2 was detected in trace amounts in the extract. For comparison, when an $\mathrm{CH}_{3} \mathrm{CN}$ extract of the sample at concentration of $260 \mathrm{mg} / \mathrm{ml}$ was subjected to LC-MS-MS analysis, neither 1 nor 2 was

Table 5. Precursor/Product Ion Pairs Selected for Multiple Reaction Monitoring (MRM) of Compounds $\mathbf{1}$ and $\mathbf{2}$

\begin{tabular}{cccc}
\hline \hline Compound & Precursor ion $(m / z)$ & Product ion $(m / z)$ & ESI cone voltage $(\mathrm{V})$ \\
\hline $\mathbf{1}$ & {$[\mathrm{M}+\mathrm{H}]^{+} 537$} & {$\left[\mathrm{M}+\mathrm{H}-\mathrm{H}_{2} \mathrm{O}\right]^{+} 519$} & 30 \\
& {$[\mathrm{M}+\mathrm{H}]^{+} 537$} & {$\left[\mathrm{M}+\mathrm{H}-2 \mathrm{H}_{2} \mathrm{O}\right]^{+} 501$} & 7 \\
& {$[\mathrm{M}+\mathrm{H}]^{+} 537$} & {$\left[\mathrm{M}+\mathrm{H}-3 \mathrm{H}_{2} \mathrm{O}-\mathrm{MeOH}\right]^{+} 451$} & 7 \\
2 & {$[\mathrm{M}+\mathrm{H}]^{+} 535$} & {$\left[\mathrm{M}+\mathrm{H}-\mathrm{H}_{2} \mathrm{O}\right]^{+} 517$} & 30 \\
& {$[\mathrm{M}+\mathrm{H}]^{+} 535$} & 211 & 30 \\
& {$[\mathrm{M}+\mathrm{H}]^{+} 535$} & 143 & 30 \\
\end{tabular}

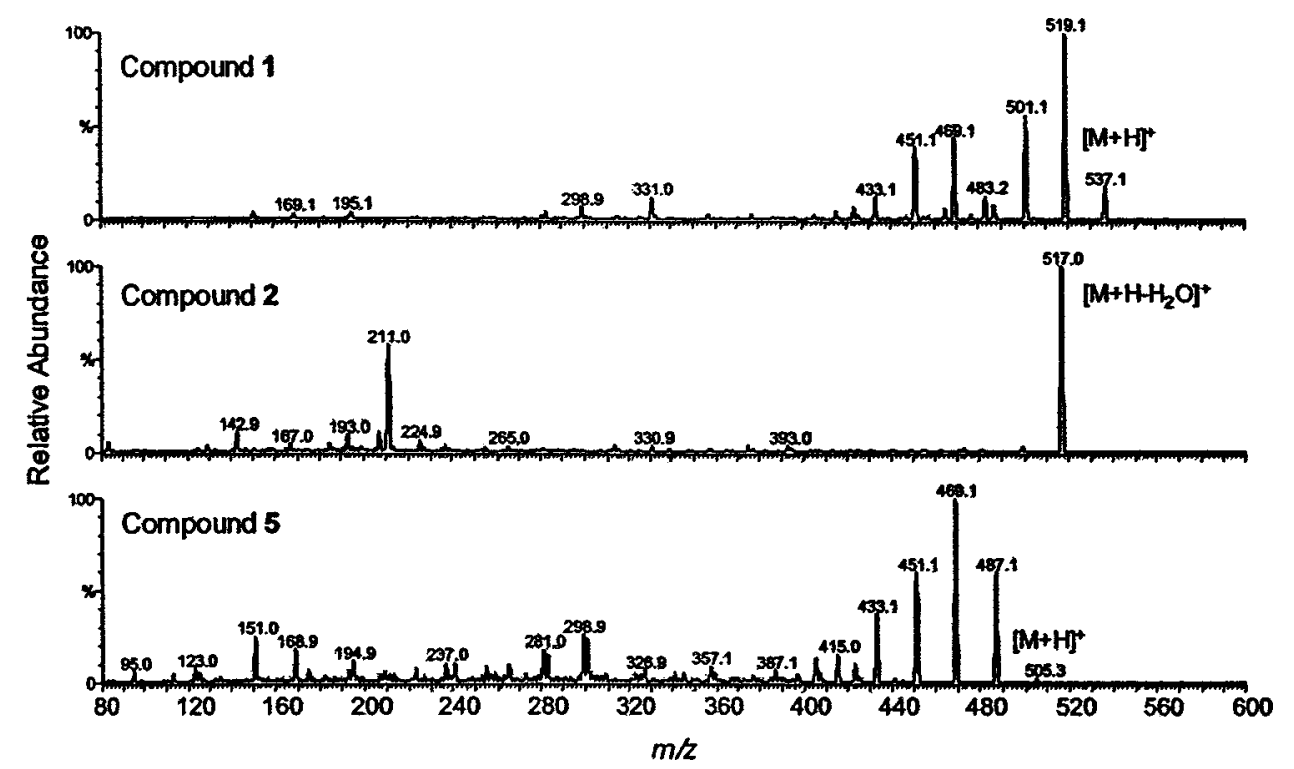

Fig. 2. Positive Ion Electrospray Product Ion Tandem Mass Spectra with CID of Compounds 1, 2, and 5 


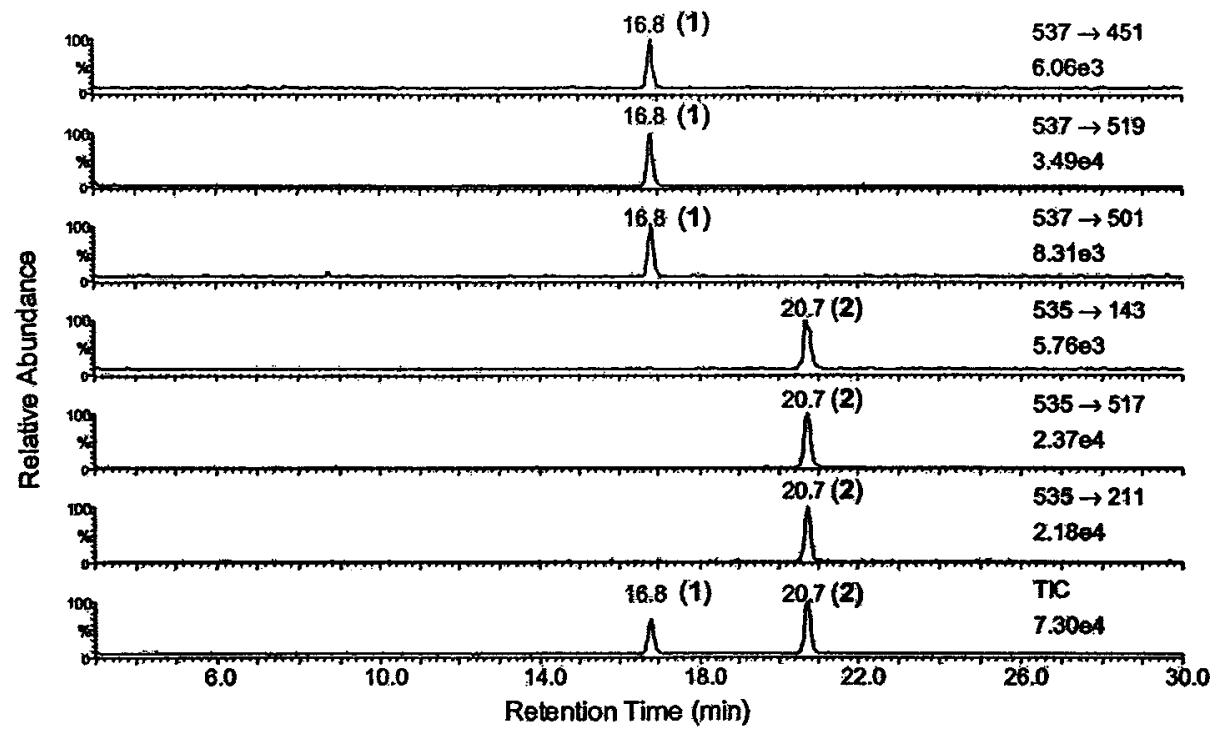

Fig. 3. LC-MS-MS MRM Chromatograms of a Reference Standard Mixture of $\mathbf{1}$ and $\mathbf{2}$

The retention times of $\mathbf{1}$ and $\mathbf{2}$ were observed at 16.8 and $20.7 \mathrm{~min}$, respectively.

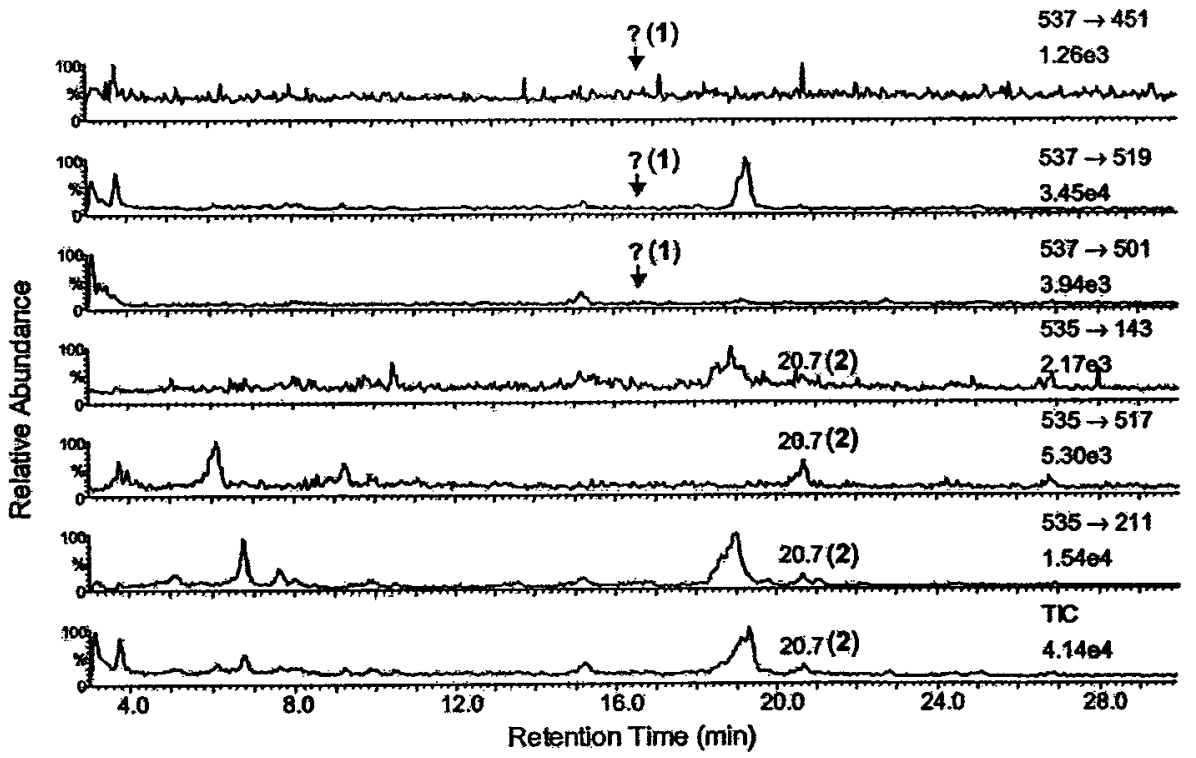

Fig. 4. LC-MS-MS MRM Chromatograms of a Methanol Extract of the Dried Leaves and Stems of P. philadelphica

A question mark indicates that at the retention time, the compound of interest was not detected (LOD $\approx 200 \mathrm{pg}$ on-column).

detected (Fig. 5). Moreover, both 1 and 2 were detected in the same $\mathrm{MeOH}$ extract (Fig. 6) but not an $\mathrm{CH}_{3} \mathrm{CN}$ extract (data not shown) after each extract was stored at room temperature for one week. The identification of $\mathbf{1}$ and $\mathbf{2}$ in the $\mathrm{MeOH}$ extract was based on co-elution with standards, the simultaneous appearance of diagnostic MRM signals during LC-MS-MS and the comparison of ratios of the MRM peak areas for $1(1: 7.62: 1.77$, corresponding to $\mathrm{m} / \mathrm{z} 537 \rightarrow 451$, $537 \rightarrow 519,537 \rightarrow 501$, respectively) and for $2(1: 4.59: 3.53$, corresponding to $m / z 535 \rightarrow 143,535 \rightarrow 517,535 \rightarrow 211$, respectively) with those obtained for the purified standards ( $1: 7.68: 1.69$ for $\mathbf{1} ; 1: 4.55: 3.76$ for 2 ). Accordingly, $\mathbf{1}$ and 2 were determined to be artifacts generated from 5 and ixocarpalactone $\mathrm{B}$, respectively, due to the use of $\mathrm{MeOH}$ in the extraction and purification of these withanolides. These observations provide further evidence that withanolides with a 2-en-1-one unit will form Michael addition adducts in $\mathrm{MeOH}$. Therefore, the use of $\mathrm{MeOH}$ as a solvent in the isolation of withanolides should be avoided. In contrast, compounds $3-5$ were verified as authentic natural withanolides because they were detected in both $\mathrm{MeOH}$ and $\mathrm{CH}_{3} \mathrm{CN}$ extracts of the dried leaves and stems of $P$. philadelphica using the same strategies applied to $\mathbf{1}$ and $\mathbf{2}$ (data not shown).

For the qualitative and quantitative analysis of ixocarpalactone A (5) in commercially available fresh tomatillos (the fruits of $P$. philadelphica), an $\mathrm{CH}_{3} \mathrm{CN}$-soluble extract was prepared and subjected to LC-MS-MS analysis. Prior to LC-MS-MS quantification, standard 5 was introduced into the electrospray ionization source of the mass spectrometer via infusion in $\mathrm{H}_{2} \mathrm{O}-\mathrm{CH}_{3} \mathrm{CN}(1: 1, \mathrm{v} / \mathrm{v}$, containing $0.1 \%$ formic acid). CID experiments on 5 were carried out to optimize instrumental operating conditions of the mass spec- 


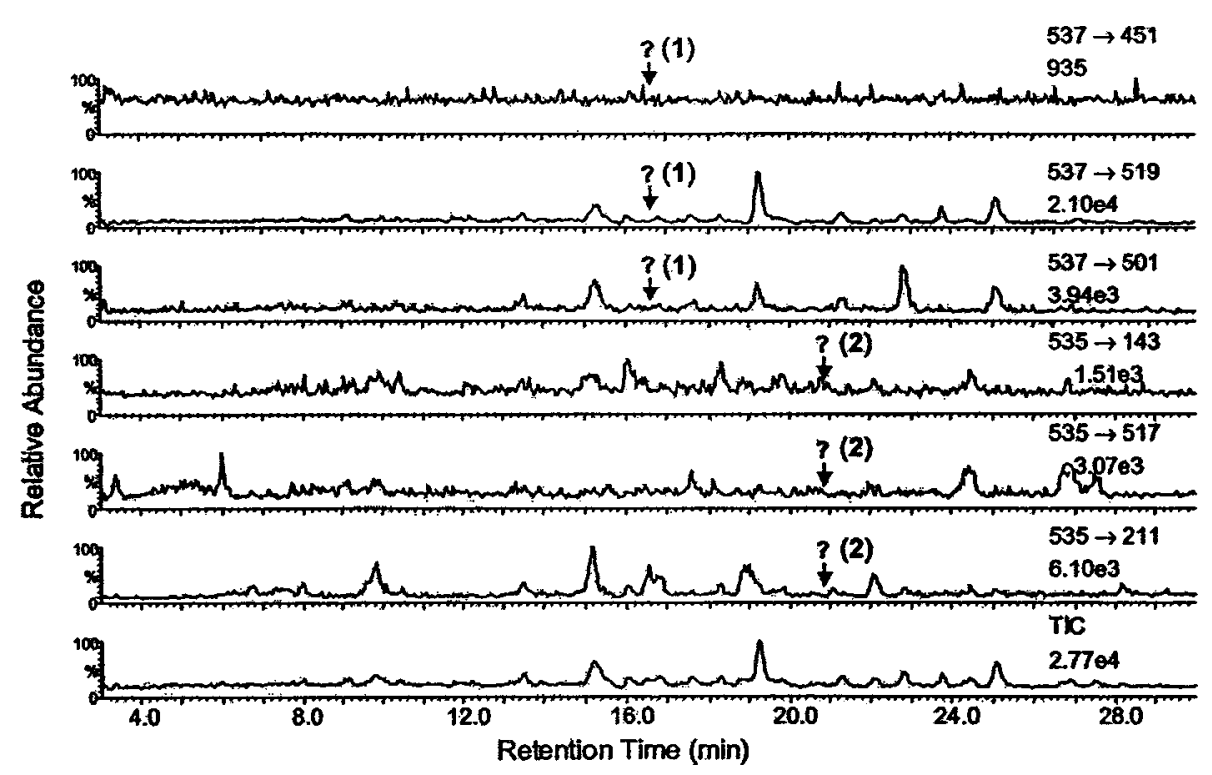

Fig. 5. LC-MS-MS MRM Chromatograms of an Acetronitrile Extract of the Dried Leaves and Stems of P. philadelphica A question mark indicates that at the retention time, the compound of interest was not detected (LOD $\approx 200 \mathrm{pg}$ on-column).

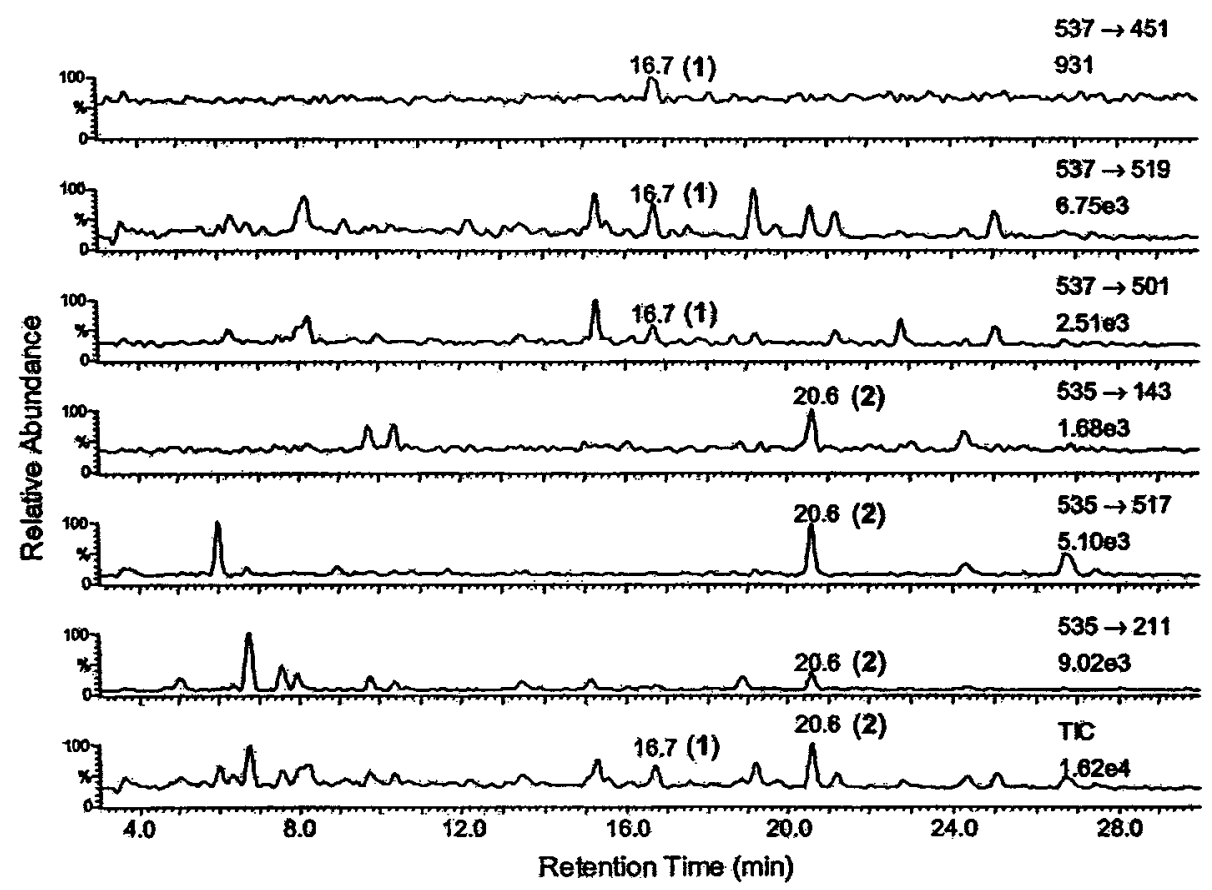

Fig. 6. LC-MS-MS MRM Chromatograms of a Methanol Extract of the Dried Leaves and Stems of P. philadelphica After Storage for 7 Days Compounds 1 and 2 were observed with retention times of 16.7 and 20.6 min, respectively.

trometer and to select precursor/product ion pairs to be used for MRM during LC-MS-MS. The CID product ion mass spectrum of the $[\mathrm{M}+\mathrm{H}]^{+}$ion at $m / z 505$ is shown in Fig. 2. The most abundant ion pair $(\mathrm{m} / \mathrm{z} 505 \rightarrow 469)$ was chosen for LC-MS-MS quantification. Eight non-zero working standard solutions were prepared to produce a LC-MS-MS calibration curve containing 5 in concentrations corresponding to 0.5 $90 \mathrm{ng}$ per HPLC injection, with 4-androstene-3,17-dione (MW 286) as the internal standard. As shown in Fig. 7, the standard calibration curve for $\mathbf{5}$ was linear over the range of $0.5-90 \mathrm{ng}$ with a correlation coefficient $\left(\mathrm{R}^{2}\right)$ of 0.994 . The LOD of the LC-MS-MS analysis for 5 was 200 pg on-column
( $\mathrm{S} / \mathrm{N}>3$, see the insert of Fig. 7) and the limit of quantification was $400 \mathrm{pg}$ on-column (data not shown). A typical LCMS-MS chromatogram of an $\mathrm{CH}_{3} \mathrm{CN}$ extract of commercially available fresh tomatillos is shown in Fig. 8. The results showed that the sample of the fresh fruits of $P$. philadelphica investigated contained ixocarpalactone A (5) at a concentration of $143 \pm 4.53 \mathrm{ppb}$. Should ixocarpalactone A (5) ultimately prove to be a promising cancer chemopreventive agent, its detection as a constituent of the edible tomatillo fruit in the present study will be of significance. 


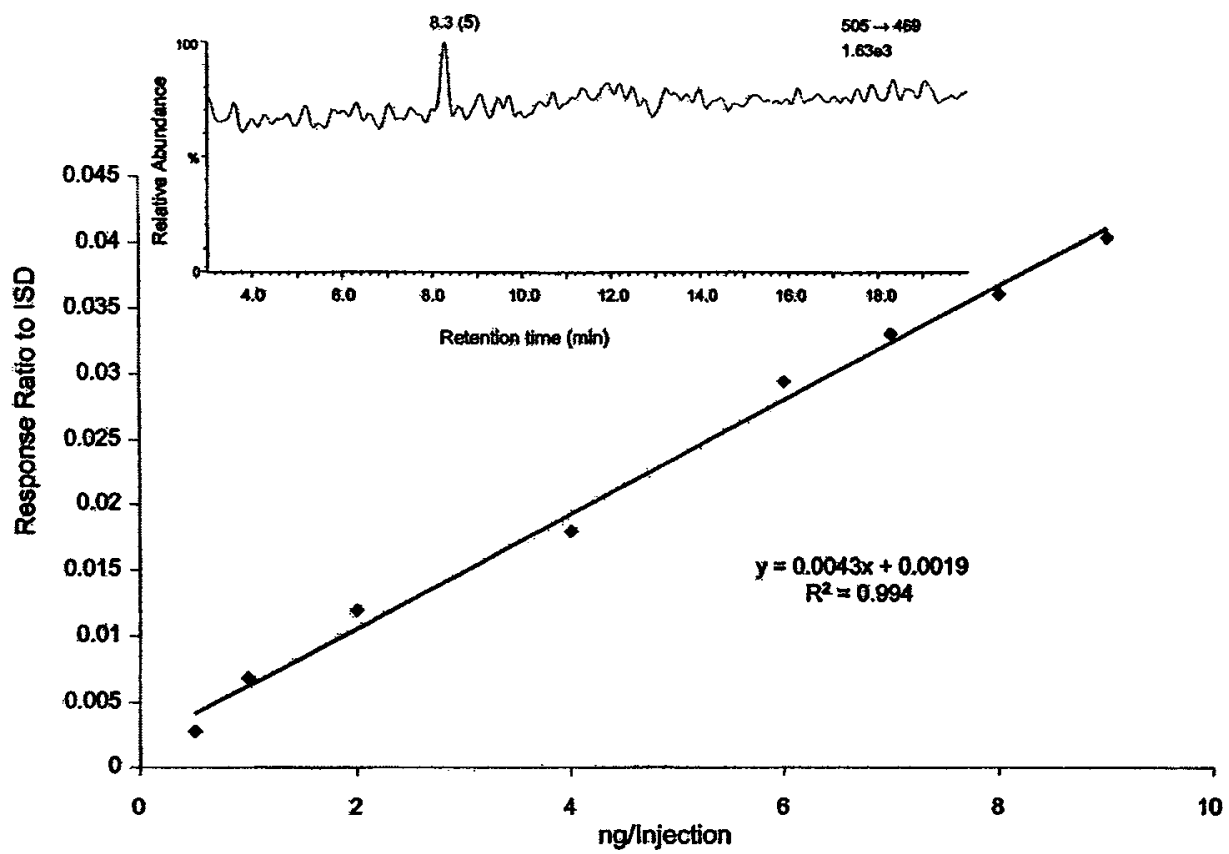

Fig. 7. LC-MS-MS Calibration Curve for 5 Using a Precursor/Product Ion Pair of $m / z 505 \rightarrow 469$ (for 5) and $287 \rightarrow 109$ (for the Internal Standard, 4-Androstene-3,17-dione)

The calibration curve was constructed using a ratio of 5 to 4 -androstene-3,17-dione throughout the concentration range. The insert shows LC-MS-MS chromatograms of the compound at the limit of detection of $200 \mathrm{pg}$ on column.

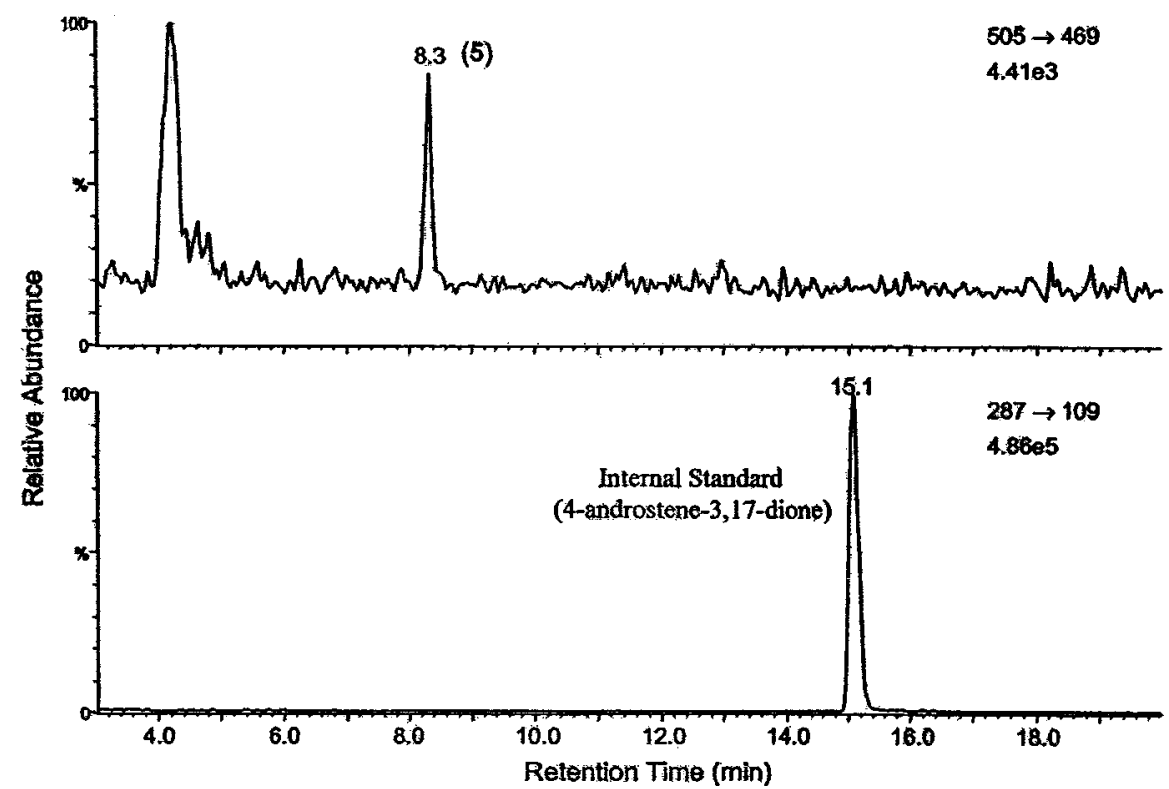

Fig. 8. LC-MS-MS MRM Chromatograms of an Acetonitrile Extract of Commercially Available Fresh Tomatillos (P. philadelphica Fruits)

The retention times of $\mathbf{5}$ and the internal standard, 4-androstene-3,17-dione, were observed at retention times of 8.3 and 15.1 min, respectively.

\section{Experimental}

General Melting points were determined using a Fisher-Johns melting point apparatus and are uncorrected. Optical rotations were measured with a Perkin-Elmer 241 automatic polarimeter. UV spectra were obtained with a Beckman DU-7 spectrometer. CD measurements were performed using a JASCO-810 CD spectropolarimeter. IR spectra were run on an ATI Mattson Genesis Series FT-IR spectrophotometer. NMR spectral data were recorded at room temperature on Bruker DPX-360 and DRX-500 MHz spectrometers with tetramethylsilane (TMS) as internal standard. High-resolution electrospray exact mass measurements were obtained on a Micromass (Manchester, U.K.) QTOF II mass spectrometer. Semi-preparative HPLC was performed on a Waters (Milford, MA, U.S.A.) HPLC system consisting of two model 515 pumps and a 996 photodiode array detector (monitoring at $202 \mathrm{~nm}$ and
$217 \mathrm{~nm}$ ) with a $20 \times 250 \mathrm{~mm}, 5-\mu \mathrm{m}$, YMC-Pack ODC-AQ column (YMC, Wilmington, NC, U.S.A.) at $8 \mathrm{ml} / \mathrm{min}$. Column chromatography was carried out with silica gel G (Merck, 230 - 400 mesh). Analytical thin-layer chromatography (TLC) was performed on precoated $250 \mu \mathrm{m}$ thick silica gel 60 $\mathrm{F}_{254}$ aluminum plates (Merck, Germany). Compounds were visualized by dipping TLC plates into phosphomolybdic acid reagent (Aldrich, Milwaukee, WI, U.S.A.) following by charring at $110^{\circ} \mathrm{C}$ for $5-10 \mathrm{~min}$.

Plant Material The leaves and stems $(36.4 \mathrm{~kg})$ of P. philadelphica were harvested before fruiting in the summer of 2000 from plants grown at the University of Illinois Pharmacognosy Field Station, Downers Grove, IL, U.S.A. Harvesting was performed approximately every two weeks starting at the end of July and ending in the middle of September. A voucher specimen (PC3070) of leaves and stems was deposited at the University of Illinois 
Pharmacognosy Field Station.

The fruits of $P$. philadelphica ( $c a .200 \mathrm{~g}$ fresh weight) were purchased commercially from a local supermarket (Treasure Island Foods, Clyborne Street, Chicago, IL, U.S.A.) in July 2002. The plant material was compared with a taxonomically identified sample deposited in the Field Museum of Natural History, Chicago, IL, under the acquisition number Soejarto and Perez, 9777.

Biological Assays for the Induction of Quinone Reductase (QR) with Cultured Mouse Hepatoma Cells For the evaluation of plant extracts, fractions, and pure compounds as inducers of QR, cultured murine hepatoma $1 \mathrm{c} 1 \mathrm{c} 7$ cells were used as described previously. ${ }^{7,13)}$ Enzyme specific activity was expressed as $\mathrm{CD}$, the concentration required to double the induction of $\mathrm{QR}$. $\mathrm{IC}_{50}$ (half-maximal inhibitory concentration of cell viability) and $\mathrm{CI}$ (chemoprevention index, $\mathrm{IC}_{50} / \mathrm{CD}$ ) values were also determined.

Extraction and Isolation The dried and milled leaves and stems $\left(36.4 \mathrm{~kg}\right.$ ) of P. philadelphica were extracted by maceration with $\mathrm{MeOH}-\mathrm{H}_{2} \mathrm{O}$ $(9: 1)$ three times $(3 \times 901)$ at room temperature, for three days each. After filtration and evaporation of the solvent under reduced pressure, the combined crude methanolic extract was partitioned in turn with $n$-hexane $(3 \times$ $21)$ and EtOAc $(4 \times 21)$, to afford a dried EtOAc-soluble extract $(180 \mathrm{~g})$, which was subjected to silica gel column chromatography by elution with increasing concentrations of $\mathrm{MeOH}$ in $\mathrm{CHCl}_{3}$ to give six major fractions (F01-F06). Fraction F03 (13 g, $\left.\mathrm{SiO}_{2}, \mathrm{CHCl}_{3}-\mathrm{MeOH}, 30: 1\right)$ was subjected to silica gel column chromatography by elution with mixtures of $n$-hexane2-propanol $(85: 15)$ to give $2(440 \mathrm{mg})$. In turn, ixocarpalactone A $(\mathbf{5}, 3.0 \mathrm{~g})$ was crystallized in $\mathrm{CHCl}_{3}-\mathrm{MeOH}$ from fraction $\mathrm{F} 05\left(25 \mathrm{~g}, \mathrm{SiO}_{2}, \mathrm{CHCl}_{3}-\right.$ $\mathrm{MeOH}, 20: 1),{ }^{8)}$ and the mother liquor extract was further fractionated over a silica gel column by elution with gradient mixtures of $n$-hexane-2propanol to afford $\mathbf{5}(150 \mathrm{mg}, n$-hexane-2-propanol, $3: 1)$, and a subfraction (300 mg; $n$-hexane-2-propanol, $4: 1)$, which afforded 1 (90 mg), 3 (15 mg), $4(4 \mathrm{mg})$, and an additional amount of $5(50 \mathrm{mg})$ by reversed-phase HPLC (YMC-Pack ODC-AQ column, $\mathrm{CH}_{3} \mathrm{CN}-\mathrm{H}_{2} \mathrm{O}, 4.8: 3.2 ; t_{\mathrm{R}} 19.6,21.9,23.2$, and $29.5 \mathrm{~min}$, respectively).

2,3-Dihydro-3 $\beta$-methoxyixocarpalactone A (1): White amorphous powder, $\mathrm{mp} 240-243^{\circ} \mathrm{C},[\alpha]_{\mathrm{D}}^{20}-39^{\circ}\left(c=0.088, \mathrm{CH}_{3} \mathrm{CN}\right)$. IR (film) $\mathrm{cm}^{-1}: 3352$, 1737, 1692, 1455, 1371, 1352, 1185, 1093. UV $\lambda_{\max }\left(\mathrm{CH}_{3} \mathrm{CN}\right) \mathrm{nm}(\log \varepsilon)$ : 197 (3.91), $221 \mathrm{sh}$ (3.21), 273 (2.70). $\mathrm{CD}\left(\mathrm{CH}_{3} \mathrm{CN}\right) \mathrm{nm}: \Delta \varepsilon_{290}-21027$. HRMS m/z: $537.3068[\mathrm{M}+\mathrm{H}]^{+}$(Calcd for $\left.\mathrm{C}_{29} \mathrm{H}_{45} \mathrm{O}_{9} 537.3064\right) .{ }^{1} \mathrm{H}-$ and ${ }^{13} \mathrm{C}-$ NMR: see Tables 1 and 3, respectively.

2,3-Dihydro-3 $\beta$-methoxyixocarpalactone B (2): White amorphous powder, mp $190-192^{\circ} \mathrm{C},[\alpha]_{\mathrm{D}}^{20}-117^{\circ}\left(c=0.076, \mathrm{CH}_{3} \mathrm{CN}\right)$. IR (film) $\mathrm{cm}^{-1}$ : $3463,1762,1708,1459,1219,1093,1018$. UV $\lambda_{\max }\left(\mathrm{CH}_{3} \mathrm{CN}\right) \mathrm{nm}(\log \varepsilon)$ : 198 (3.82), 236 (3.08), 283 (2.76). CD ( $\left.\mathrm{CH}_{3} \mathrm{CN}\right) \mathrm{nm}: \Delta \varepsilon_{217}-10335, \Delta \varepsilon_{290}$ -17992 . HR-MS $m / z$ : $535.2931[\mathrm{M}+\mathrm{H}]^{+}\left(\right.$Calcd for $\left.\mathrm{C}_{29} \mathrm{H}_{43} \mathrm{O}_{9} 535.2907\right)$. ${ }^{1} \mathrm{H}$ - and ${ }^{13} \mathrm{C}$-NMR: see Tables 1 and 3, respectively.

2,3-Dihydroixocarpalactone B (3): White amorphous powder, $\mathrm{mp} 178$ $180^{\circ} \mathrm{C},[\alpha]_{\mathrm{D}}^{20}-93^{\circ}\left(c=0.089, \mathrm{CH}_{3} \mathrm{CN}\right)$. IR (film) cm $\mathrm{cm}^{-1}: 3442,1763,1697$, 1457, 1211. UV $\lambda_{\max }\left(\mathrm{CH}_{3} \mathrm{CN}\right) \mathrm{nm}(\log \varepsilon): 196$ (3.90), 221 (3.25). CD $\left(\mathrm{CH}_{3} \mathrm{CN}\right) \mathrm{nm}: \Delta \varepsilon_{217}-8614, \Delta \varepsilon_{295}-9840$. HR-MS m/z: $505.2816[\mathrm{M}+\mathrm{H}]^{+}$ (Calcd for $\mathrm{C}_{28} \mathrm{H}_{41} \mathrm{O}_{8}$ 505.2801). ${ }^{1} \mathrm{H}-$ and ${ }^{13} \mathrm{C}-\mathrm{NMR}$ : see Tables 2 and 3, respectively.

$4 \beta, 7 \beta, 20 R$-Trihydroxy-1-oxowitha-2,5-dien-22,26-olide (4): White amorphous solid, $[\alpha]_{\mathrm{D}}^{20}-26^{\circ}\left(c=0.082, \mathrm{CH}_{3} \mathrm{CN}\right)$. IR (film) $\mathrm{cm}^{-1}: 3425,1729$, $1679,1456,1378,1197$. UV $\lambda_{\max }\left(\mathrm{CH}_{3} \mathrm{CN}\right) \mathrm{nm}(\log \varepsilon): 201$ (4.28), 261 (3.46). HR-MS $m / z: 495.2757[\mathrm{M}+\mathrm{Na}]^{+}\left(\mathrm{Calcd}\right.$ for $\mathrm{C}_{28} \mathrm{H}_{40} \mathrm{O}_{6} \mathrm{Na}$ 495.2723). ${ }^{1} \mathrm{H}-$ and ${ }^{13} \mathrm{C}-\mathrm{NMR}$ : see Tables 2 and 3, respectively.

Ixocarpalactone A (5): White amorphous powder, mp $290-292^{\circ} \mathrm{C},[\alpha]_{\mathrm{D}}^{20}$ $+83^{\circ}\left(c=0.15, \mathrm{CH}_{3} \mathrm{CN}\right)$. (lit. mp $291-292^{\circ} \mathrm{C}$ and $294-295^{\circ} \mathrm{C},[\alpha]_{\mathrm{D}}^{25}$ $+84^{\circ}$ and $\left.+68.9^{\circ}, \mathrm{CH}_{3} \mathrm{CN}\right) .^{9,23)} \mathrm{CD}\left(\mathrm{CH}_{3} \mathrm{CN}\right) \mathrm{nm}: \Delta \varepsilon_{290}-1294, \Delta \varepsilon_{340}$ +6210 . HR-MS $m / z$ : $505.2864[\mathrm{M}+\mathrm{H}]^{+}$(Calcd for $\left.\mathrm{C}_{28} \mathrm{H}_{41} \mathrm{O}_{8} 505.2801\right)$. $\mathrm{UV},{ }^{1} \mathrm{H}$ - and ${ }^{13} \mathrm{C}$-NMR: consistent with published values. ${ }^{8}$

LC-MS-MS All organic solvents and chemicals used for this part of study were of HPLC grade (Fisher Scientific, Fair Lawn, NJ, U.S.A.). The withanolide standards were obtained from the repository of natural product isolates in our own laboratory, and their identities and purities were verified using LC-MS-MS, HPLC, and NMR. Deionized water was generated using an in-house Nano-pure water system (Barnstead, Newton, MA, U.S.A.).

The reference standards were dissolved individually in an appropriate volume of $\mathrm{CH}_{3} \mathrm{CN}$ to yield $100 \mu \mathrm{g} / \mathrm{ml}$ stock solutions. An aliquot each of compounds 1 and $2(1 \mathrm{ml})$ was mixed and diluted using $50 \% \mathrm{CH}_{3} \mathrm{CN}$ to give a standard working solution containing each standard at $10 \mu \mathrm{g} / \mathrm{ml}$. By dilution of the standard working solution with $50 \% \mathrm{CH}_{3} \mathrm{CN}$, a series of standard working solutions was obtained at levels of $2-100 \mathrm{ng} / \mathrm{ml}$. For quantification of ixocarpalactone A (5), the standard working solutions were prepared by diluting the stock $(100 \mu \mathrm{g} / \mathrm{ml})$ with $50 \% \mathrm{CH}_{3} \mathrm{CN}$ to give a concentration of $1 \mu \mathrm{g} / \mathrm{ml}$. On dilution of the standard working solution with $50 \% \mathrm{CH}_{3} \mathrm{CN}$ $(\mathrm{v} / \mathrm{v})$, calibrated working solutions at levels of $10-900 \mathrm{ng} / \mathrm{ml}$ were prepared by introducing 4-androstene-3,17-dione (MW 286) as the internal standard at a concentration of $1 \mu \mathrm{g} / \mathrm{ml}$. All stock solutions and working solutions were stored at $-20^{\circ} \mathrm{C}$ and brought to room temperature before use.

The dried and milled leaves and stems $(0.5 \mathrm{~g})$ of $P$. philadelphica were sonicated in $15 \mathrm{ml}$ of $\mathrm{HPLC} \mathrm{MeOH}$ at $25-30^{\circ} \mathrm{C}$ for $60 \mathrm{~min}$. After cooling, the mixture was filtered through Whatman (Clifton, NJ, U.S.A.) No. 1 filter paper into a $250-\mathrm{ml}$ round-bottom flask. The marc was extracted twice more in the same manner, with the final residue being washed with $\mathrm{MeOH}$. The combined extract was evaporated under reduced pressure, and the resulting residue was re-dissolved and transferred using $\mathrm{MeOH}$ into a $10-\mathrm{ml}$ volumetric flask and made up to volume with $\mathrm{MeOH}$. Duplicate sample solutions were prepared for analysis. For comparison, the sample solution $(260 \mathrm{mg} / \mathrm{ml})$ was prepared in the same way using $\mathrm{CH}_{3} \mathrm{CN}$ instead $\mathrm{MeOH}$. Both the $\mathrm{MeOH}$ and $\mathrm{CH}_{3} \mathrm{CN}$ extracts were centrifuged at $5000 \mathrm{rpm}$ and then analyzed using LC-MS-MS.

Commercially available fresh tomatillos $(50 \mathrm{~g})$ were blended, extracted with $\mathrm{CH}_{3} \mathrm{CN}$ for $10 \mathrm{~min}(3 \times 80 \mathrm{ml})$, and then filtered through Whatman No. 5 filter paper into a $250-\mathrm{ml}$ round-bottom flask. The combined extract was evaporated under reduced pressure, and the resulting residue was re-dissolved and transferred using $\mathrm{CH}_{3} \mathrm{CN}$ into a $100-\mathrm{ml}$ volumetric flask and made up to volume with $\mathrm{CH}_{3} \mathrm{CN}$. In the same manner as mentioned above, the $\mathrm{CH}_{3} \mathrm{CN}$ extract was centrifuged and then analyzed using LC-MS-MS.

For verification of the origin of $\mathbf{1}$ and $\mathbf{2}$, LC-MS-MS was carried out using a Waters Alliance 2690 HPLC system interfaced to a Micromass Quattro II electrospray triple quadrupole mass spectrometer. A Supelco (Bellefonte, PA, U.S.A.) $\mathrm{C}_{18}$ column $(4.6 \times 250 \mathrm{~mm}, 5-\mu \mathrm{m}$, Serial \#504971) was used for HPLC separations. The sample injection volume was $10 \mu$. The solvent system consisted of a $30 \mathrm{~min}$ linear gradient from $20-50 \% \mathrm{CH}_{3} \mathrm{CN}$ in water containing $0.5 \%$ acetic acid at a flow rate of $1 \mathrm{ml} / \mathrm{min}$. The column effluent was split so that approximately $20 \%$ was transferred to the mass spectrometer.

For the quantification of $\mathbf{5}$, the sample solution was injected onto a Waters Xterra MS $\mathrm{C}_{18}$ column $(2.1 \times 100 \mathrm{~mm}, 3.5-\mu \mathrm{m}$, Serial \#T10731E-14). The solvent system consisted of a 20 min linear gradient from $20-55 \% \mathrm{CH}_{3} \mathrm{CN}$ in water containing $0.1 \%$ formic acid. In this case, the entire column effluent was transferred into the mass spectrometer without splitting.

During LC-MS-MS, the electrospray ion source of the mass spectrometer was operated at $140^{\circ} \mathrm{C}$ in the positive ion mode to generate $[\mathrm{M}+\mathrm{H}]^{+}$ions of the compounds of interest. Nitrogen was used as both nebulizing and drying gas at a flow rate of $201 / \mathrm{h}$ and $450 \mathrm{l} / \mathrm{h}$, respectively. Following the selection of the protonated precursor ions by the first quadrupole mass analyzer, collision-induced dissociation (CID) was carried out using argon as the collision gas at $1 \times 10^{-3}$ mbar with a collision energy of $7-25 \mathrm{eV}$. Both the first and last quadrupole mass analyzers were operated at unit-mass resolution. During multiple reaction monitoring (MRM), the dwell time was set at $0.2 \mathrm{~s}$ for each of precursor/product ion pairs.

Acknowledgments This research was supported by Program Project P01 CA48112 funded by the National Cancer Institute, NIH, Bethesda, MD, U.S.A. We thank Mr. Steven Totura, University of Illinois Pharmacognosy Field Station, Downers Grove, IL, U.S.A., for the plant cultivation and $\mathrm{MeOH}$-soluble extract preparation. We are grateful to the Research Resources Center, University of Illinois at Chicago (UIC), for the provision of certain NMR spectroscopic equipment used in this investigation. We thank Mr. Qi Xu, Department of Chemistry, College of Liberal Arts and Sciences, UIC, for obtaining the CD spectroscopic data.

\section{References}

1) Glotter E., Nat. Prod. Rep., 8, 415-440 (1982).

2) Raffauf R. F., Shemluck M. J., Le Quesne P. W., J. Nat. Prod., 54, 1601-1606 (1991).

3) Ray A. B., Gupta M., "Progress in the Chemistry of Organic Natural Products," Vol. 63, ed. by Herz W., Kirby G. W., Moore R. E., Steglich W., Tam Ch., Springer Verlag, New York, 1994, pp. 1-106.

4) Ascher K. R. S., Nemny N. E., Eliyahu M., Kirson I., Abraham A., Glotter E., Experientia, 36, 998-999 (1980).

5) Chiang H. C., Jaw S. M., Chen C. F., Kan W. S., Anticancer Res., 12, 837-843 (1992).

6) Kennelly E. J., Gerhäuser C., Song L. L., Graham J. G., Beecher C. W. W., Pezzuto J. M., Kinghorn A. D., J. Agric. Food Chem., 45, 37713777 (1997). 
7) Misico R. I., Song L. L., Veleiro A. S., Cirigliano A. M., Tettamanzi M. C., Burton G., Bonetto G. M., Nicotra V. E., Silva G. L., Gil R. R., Oberti J. C., Kinghorn A. D., Pezzuto J. M., J. Nat. Prod., 65, 677680 (2002).

8) Su B. N., Misico R., Park E. J., Santarsiero B. D., Mesecar A. D., Fong H. H. S., Pezzuto J. M., Kinghorn A. D., Tetrahedron, 58, 3453-3466 (2002).

9) Kirson I., Cohen A., Greenberg M., Gottlieb H. E., Glotter E., Varenne P., Abraham A., J. Chem. Res. (M), 103, 1178-1195 (1979).

10) Bock M. A., Sanchez-Pilcher J., McKee L. J., Ortiz M., Plant Foods Hum. Nutr., 48, 127-133 (1995).

11) Pezzuto J. M., Biochem. Pharmacol., 53, 121-133 (1997).

12) Kinghorn A. D., Fong H. H. S., Farnsworth N. R., Mehta R. G., Moon R. C., Moriarty R. M., Pezzuto J. M., Curr. Org. Chem., 2, 597-612 (1998).

13) Prochaska H. J., Santamaria A. B., Anal. Biochem., 169, 328-336 (1988).
14) Bukovits G. J., Gros E. G., Phytochemistry, 18, 1237-1239 (1979).

15) Pelletier S. W., Mody N. V., Nowacki J., Bhattacharyya J., J. Nat. Prod., 42, 512-521 (1979).

16) Burton G., Valeiro A. S., Gros E. G., J. Chromatogr., 315, 435-440 (1984).

17) Veleiro A. S., Burton G., Gros E. G., Phytochemistry, 24, 1799-1802 (1985).

18) Veleiro A. S., Burton G., Gros E. G., Phytochemistry, 24, 2263-2265 (1985).

19) Neogi P., Sahai M., Ray A. B., Phytochemistry, 26, 243-247 (1987).

20) Alfonso D., Kapetanidis I., Phytochemistry, 36, 179-183 (1994).

21) Kuroyanagi M., Shibata K., Umehara K., Chem. Pharm. Bull., 47, 1646-1649 (1999).

22) Glotter E., Kirson I., Abraham A., Lavie D., Tetrahedron, 29, 1353 1364 (1973).

23) Abdullaev N. D., Vasina O. E., Maslennikova V. A., Abubakirov N. K., Chem. Nat. Compd., 22, 300-305 (1986). 